\title{
CONGRESS, THE FCC, AND THE SEARCH FOR THE PUBLIC TRUSTEE
}

\author{
NeAL DeVins* \\ I \\ INTRODUCTION
}

Welcome to the constitutional backwater-a place where Rupert Murdoch and Ted Kennedy battle over the Senator's weight and the press baron's ownership of the Boston Herald; where Supreme Court nominee Clarence Thomas's truthfulness before the Senate Judiciary Committee is challenged by a D.C. Circuit insider; where a regulatory agency hopes its constitutional arguments will be rejected in court and respected in Congress; where President Ronald Reagan alternatively abides by and disregards Department of Justice constitutional interpretations; where President George Bush's regulatory appointees and Solicitor General openly battle each other before the Supreme Court; and where members of Congress perceive constitutional analysis as superfluous. Welcome to the world of the Federal Communications Commission ("FCC") circa 1982-1992.

The story begins with the 1980 election of Ronald Reagan. Advocating the substitution of marketplace efficiencies for bureaucratic failures, ${ }^{1}$ Reagan appointed communications free-marketeers Mark Fowler (1981-1987) and Dennis Patrick (1987-1989) to chair the FCC. This changing of the guard, to no one's surprise, did not sit well with the FCC's pro-regulation oversight committees in the Congress, particularly in the House. ${ }^{2}$ What is surprising is the vehemence in which congressional leadership expressed its displeasure with the FCC, and the

Copyright (C) 1993 by Law and Contemporary Problems

* Professor of Law and Lecturer in Government, College of William and Mary.

Thanks to Mark Hermann, Randy Springer, and Wendy Watson for research assistance. My interest in this project is a result of their good deeds. Thanks also to Scott Powe and Rod Smolla for their comments on an earlier draft of this article. Last but not least, I am greatly indebted to those FCC officials, congressional staffers, and attorneys who not only participated in the drama recounted in this article but also shared their thoughts with me and my research assistants.

1. See generally GeORge C. EAdS \& Michael FiX, Relief OR Reform? REAGan's Regulatory Dilemma (1984); THe ReaGAn Experiment (John L. Palmer \& Isabel V. Sawhill eds., 1982).

2. The 1980 Reagan landslide brought with it Republican control of the Senate. Senate oversight of the FCC increased significantly in 1984 when the Democrats regained control of the Senate. The bulk of FCC oversight, however, is the province of the House Energy and Commerce Committee. Aside from a more lopsided Democratic majority, Energy and Commerce is a "power" committee notorious for its vigorous oversight. See Mark C. Miller, Congress and the Constitution: A Tale of Two Committees (forthcoming, on file with author). 
ways in which the Commission sought to advance its deregulatory agenda in the face of countervailing legislative pressures.

This struggle between the FCC and Congress was so fierce during the Reagan years that George Bush's efforts to soothe FCC-congressional relations by naming less confrontational, less ideological nominees accomplished next to nothing. ${ }^{3}$ With the election of Bill Clinton to the White House and his naming of Democrat Reed Hundt to chair the FCC, this decade-old war between the Commission and its oversight committees appears to be at an end. This article focuses on the struggle that preceded this promised (if not promising) era of placidity. This retrospective is far from nostalgic; to the contrary, it provides a revealing look at the uses and abuses of constitutional interpretation by an independent agency in its efforts to advance its (de)regulatory agenda.

The FCC saw the Constitution as a political tool to support its deregulatory agenda. When political circumstances allowed the FCC to invoke the Constitution to support its political agenda, the FCC paid homage to the supreme law of the land. When the political costs of advancing its constitutional interpretation were high, the FCC did not abide by its constitutional scruples. The Reagan and Bush White Houses behaved much the same. Fairness doctrine legislation was vetoed by Reagan on constitutional grounds, but constitutional concerns were never raised by Reagan in his approval of race and gender preferences. The Bush White House purposefully selected FCC Commissioners who disavowed Bush Justice Department constitutional interpretations. Congress's approach to constitutional decisionmaking was more cavalier than that of either the FCC or the White House; Congress was simply unimpressed with and untroubled about constitutional interpretation. Congress did not even pay lip service to constitutional concerns raised by the FCC; instead, the FCC was labelled a political malfeasant hiding behind an irrelevant constitutional subterfuge. The courts, finally, were extraordinarily activist in overseeing the FCC: originating FCC policymaking, demanding that the FCC articulate its decisionmaking in constitutional terms, and scrutinizing FCC constitutional arguments. Constitutional decisionmaking by both the U.S. Supreme Court and the D.C. Circuit Court of Appeals was more readily explained by ideology than fidelity to constitutional precedent.

This article details the features of constitutional politics involving independent agencies through an examination of FCC efforts to repudiate regulatory initiatives designed to facilitate diversity in broadcasting. Part II provides a brief overview of the conflict between the deregulatory FCC and the regulatory Congress. Parts III through VI focus on the particulars of four conflicts between

3. For a discussion of Bush Commission efforts to work with Congress, see infra part V(b). The failure of these efforts is apparent. Energy and Commerce staffer Colin Crowell perceived FCC-Hill relations to be as bad during the Bush Administration as the Reagan Administration. Telephone interview with Colin Crowell (Sept. 25, 1992)[hereinafter Crowell interviews]. See also Mark Conrad, FCC Broadcast Rules Review Continues on its Rocky Road, N.Y. L.J., July 24, 1992, at 5 ("persistent criticism from Congress" has made Bush FCC a "wounded, weakened, and embarrassed player in the complex communications law landscape"). 
the FCC and Congress over the broadcast diversity issue, namely: (1) the FCC repeal of the Fairness Doctrine; (2) FCC efforts to challenge the propriety of its cross-ownership prohibition banning the joint ownership of a television station and a newspaper in a single market; (3) Congress's successful efforts to fight off an FCC challenge to the awarding of preferences to minority broadcasters; and (4) the failure of the FCC and Congress to stop the judicial invalidation of comparable preferences to women broadcasters. Part VII synthesizes the lessons learned from these episodes, and comes to a sobering, but hardly revolutionary, conclusion: Congress, the FCC, the White House, and the courts placed political and ideological preferences ahead of principled constitutional decisionmaking.

\section{II}

\section{CONGRESS V. FCC: DEFINING THE "PubliC TRUST"}

Relations between the FCC and Congress are defined by legislative oversight, not statutory mandate. The FCC's statutory mandate-to regulate the use of the airwaves in the "public interest, convenience, and necessity"-is ill-defined to the point of being meaningless. ${ }^{4}$ Nearly sixty years old, this open-ended delegation governs virtually all FCC operations. Dramatic changes in the broadcasting and telecommunications industries have not prompted Congress to define more precisely the reach or objectives of FCC regulation. ${ }^{5}$

This legislative inertia is neither unusual nor surprising. Congress often prefers policymaking through oversight to avoid the pitfalls of substantive legislation. ${ }^{6}$ This reactive role in overseeing agency rulemaking is reflected in the exponential growth of committee staff, the rise of ex parte contacts between Congress and agency heads, the continued utilization of legislative vetoes (even after Chadha), and the use of riders in appropriations legislation to stifle disfavored agency initiatives. ${ }^{7}$

Congress-FCC relations are very much defined by these oversight controls. Indeed, Congress protects vigilantly and has acted to expand its oversight prerogatives and its influence over the Commission. In 1981, for instance, Congress replaced the FCC's permanent authorization with biennial authoriza-

4. 47 U.S.C. $\$ 301$ (1988).

5. See Glenn O. Robinson, The Federal Communications Commission: An Essay on Regulatory Watchdogs, 64 VA. L. REV. 169, 173-79 (1978); JOHN A. FrEEJOHN \& CHARLES R. SHIPAN, CONGRESSIONAL INFLUENCE ON ADMINISTRATIVE AGENCIES: A CASE STUDY OF TELECOMMUNICATIONS POLICY IN CONGRESS RECONSIDERED 393, 393-97 (Lawrence C. Dodd \& Bruce I. Oppenheimer eds., 4th ed. 1989). (1984).

6. See Harold H. Bruff, Legislative Formality, Administrative Rationality, 63 TEX. L. REV. 207

7. See infra notes 13-16 (ex parte contacts); Roger Davidson, The Lawmaking Congress, 56 LAw \& CONTEMP. PROBS. 99 (Autumn 1993) (rise of committee staff); Neal Devins, Regulation of Government Agencies Through Limitation Riders, 1987 DUKE L.J. 456; Louis Fisher, The Legislative Veto: Invalidated, It Survives, 56 LAw \& CONTEMP. PROBS. 273 (Autumn 1993) (persistence of post-Chadha legislative vetoes). For a discussion of Congress's use of these devices in overseeing the FCC, see Harry M. Sooshan III \& Erwin G. Krasnow, Congress and the Federal Communications Commission: The Continuing Contest for Power, 9 COMMENT L.J. 619 (1987). 
tions. $^{8}$ Unlike permanent authorizations, where must-pass legislative action is controlled by the Appropriations Committees, periodic authorizations enable the FCC's oversight committees to express their preferences and criticisms through reauthorizing legislation and not simply "annoy[ing]," "seldom ... productive" oversight hearings." Believing that "[r]egular and systematic oversight will increase Commission accountability for the implementation of congressional policy," 10 the House Telecommunications Subcommittee has more than doubled the size of its staff since 1980 to ensure that effective use is made of this reauthorization power. ${ }^{11}$

Congress's demand that no restrictions be placed on communications from members of Congress to the Commission also reveals congressional efforts to encourage FCC appreciation of the legislative will. In 1987, after the FCC claimed that Commission rules prohibited ex parte contacts with the agency on a matter that has been placed on the Commission's meeting agenda (the "sunshine period"), threats and protests from Congress convinced the FCC that the ex parte congressional contacts were supported by the "public interest for flexibility in exchanging information among policymakers." 12 Congress's desire to protect the continuous flow of information from Capitol Hill to the Commission is understandable. Congressional communications with the FCC have been described by former agency chairs as "powerful and persistent,"13 occurring "about as frequently as television commercials flash across the television screen."14 Congress jealously guards this prerogative; the White House does not. ${ }^{15}$ Ex parte White House contacts during the sunshine period are forbidden.

Congressional efforts to maximize oversight authority, as well as the failure to extend the ex parte exception to White House communications, are especially telling. In the eyes of the FCC's congressional oversight committees, the FCC is deemed an "arm of Congress." This belief is long held and pervasive. Witness House Speaker Sam Rayburn's (D-TX) advice to President Kennedy's FCC Chair Newton Minow: "Just remember one thing, son. Your agency is an arm

8. See Sooshan \& Krasnow, supra note 7, at 623-26.

9. Robinson, supra note 5 , at $\mathbf{1 8 0 .}$

10. H.R. CONF. REP. No. 208, 97th Cong., 1st Sess. 899 (1981).

11. See Micromanagement of the FCC: Here to Stay, BROADCASTING, Dec. 26, 1988, at 56, 57 [hereinafter Micromanagement].

12. Ex Parte Communications and Presentations in Commission Proceedings, 2 F.C.C.R. 6053 (1987). For further discussion, see Susan Low Bloch, Orphaned Rules in the Administrative State: The Fairness Doctrine and Other Orphaned Progeny of Interactive Deregulation, 76 GEO. L.J. 59, 126 n.270 (1987).

13. Richard E. Wiley, "Political" Influence at the FCC, 1988 DUKE L.J. 280, 282.

14. Newton N. MinOw, EQual Time: The PRivate BroAdCASTER AND THE PUblic INTEREST 36 (1964).

15. Peter Pitch, former Chief of Staff to Mark Fowler, described the White House's indifference to this ex parte dispute as proof positive that the executive viewed the Congress as the dominant overseer of FCC rulemaking. Telephone Interview with Peter Pitch (Sept. 22, 1992) [hereinafter Pitch Interview]. 
of the Congress; you belong to us. Remember that and you'll be alright."16 This belief still persists in congressional hearings. Senator Robert Packwood (ROR), for example, admonished Reagan FCC Chair Mark Fowler: "[Y]ou are a creature of Congress and you attempt to administer ... [the] laws in accordance with what you think Congress has intended."17 Along the same lines, Senate Commerce Committee Chair Ernest Hollings (D-SC) warned President Bush's FCC nominees Alfred Sikes, Andrew Barrett, and Sherrie Marshall that "[t]he Commission must follow our lead" and that "[y]ou folks take an oath to regulate, not deregulate."18

Congress's view that the FCC is independent of the White House but not Congress raises legislative expectations of FCC compliance with congressional preferences, and thereby sets the stage for testy relations between the FCC and its oversight committees. Richard Wiley, FCC Chair from 1974-1977, complained of a too confrontational, too intrusive Congress desirous of using its "supervisory tools with great regularity and enthusiasm." 19 Harry Sooshan, former counsel to the House Energy and Commerce Committee, echoed these concerns, arguing that " $[t]$ hroughout its . . . history, the Federal Communications Commission has been a target of more criticism and prolonged investigation by Congress than any other federal agency." 20 Whether, and to what degree, the Commission was solicitous of congressional preferences is quite another matter. What is clear is that Congress considered the Commission its own.

"Most people would agree," as former FCC Commissioner Glen Robinson put it, "that it is a poor dog indeed that does not know its own master." a nutshell, that is the Congress's problem with the FCC. Rather than compliantly follow legislative signals, Commissioners are sometimes more attuned to the preferences of the president who appointed them as well as their own personal predilections. Prior to 1980, Congress remained the FCC's master (in name at least) because of presidential indifference in the appointing of Commissioners. ${ }^{22}$ The 1980 election of Ronald Reagan changed all that.

Reagan undertook to expand White House influence over the administrative state while simultaneously launching a regulatory relief program designed to eliminate cost-ineffective regulations. One of the principal tools utilized by the Reagan Administration in advancing this deregulatory agenda was appointments to regulatory agencies. ${ }^{23}$ Through the appointment of like-minded individuals, as the National Journal observed, Reagan achieved "an uncommon degree of

16. Erwin G. Krasnow, Lawrence D. Longley \& Herbert A. Terry, The Politics of BROADCAST REgUlATION 89 (3d ed. 1982).

17. Joint Hearings, The Universal Telephone Service Preservation Act of 1983, 98th Cong., 1st Sess. 67 (1983).

18. Congress Asserts its Dominion Over FCC, BroadCASTING, Aug. 7, 1989, at 27.

19. Wiley, supra note 13 , at 282-83.

20. Harry M. Sooshan III \& Erwin G. Krasnow, New Checks, Balances Affect FCC Policymaking,

Legal TimES, Apr. 8, 1985, at 12.

21. Robinson, supra note 5, at 172.

22. Id. at 187-89.

23. See EADS \& FiX, supra note 1, at $140-48$. 
ideological consistency and intensity."24 At the FCC and other independent agencies, the President relied almost exclusively on regulatory appointments to make his influence felt. ${ }^{25}$ At the FCC, the President's influence was immediately felt.

Mark Fowler, Reagan's choice for FCC Chair, proudly proclaimed that he was part of the Reagan deregulatory revolution. Caricaturing the FCC as "the last of the New Deal dinosaurs" and describing himself as a "conservative populis[t]," Fowler discerned "one clear message of the 1980 elections . . . dispel this fog, the pervading environment induces not better government but bigger government. I view my job at the Federal Communications Commission as an important part of carrying out this mandate for a leaner, less intrusive federal presence throughout this country."26 Fowler's positions were echoed by fellow Reagan appointee Dennis Patrick (who replaced Fowler as Chair in 1987). In explaining the FCC's reliance upon marketplace forces and not regulation, Patrick, in a not too subtle swipe at congressional regulators, observed that "markets create the incentive to identify and to deliver to consumers what consumers want as distinguished from what we, in Washington, think consumers should want or should desire or what we, in Washington, think they need."27

Congress strongly disapproved of Fowler and Patrick's free market philosophy as well as their commitment to put that policy into place through "unregulation." On one level, this dispute was a battle over opposing philosophies regarding the propriety of regulation to serve the public interest. Members of Congress such as Al Swift (D-WA), Edward Markey (D-MA), and John Dingell (D-MI) regard broadcasters "as licensees and trustees of the public airwaves" who may be forced to serve the public interest in exchange for the government's granting them one of a limited number of broadcast licenses. ${ }^{28}$ Under this view, the market's inability to compel broadcasters to fulfill their responsibilities as public trustees speaks to "the need for sound, sensible regulations." 29 This belief that the commissioners "take an oath to regulate, not deregulate" helps explain, as Mark Fowler put it, why it "is not possible to carry out the Reagan program and have amicable relations with Congress." ${ }^{30}$

24. G. Calvin MacKenzie, quoted in Dick Kirschten, Team Players, 15 NAT'L. J. 385 (1983).

25. See Pitch interview, supra note 15; Telephone interview with Bruce Fein, FCC General Counsel under Fowler (Sept. 9, 1992) [hereinafter Fein interview].

26. Mark S. Fowler, The Federal Communications Commission 1981-1987: What the Chairman Said, 10 COMM/ENT L.J. 409, 410-11, 414-15 (1988). For an academic justification of his free market philosophy, see Mark S. Fowler \& Daniel Brenner, A Marketplace Approach to Broadcast Regulation, 60 TEX. L. REV. 207 (1982).

27. Panel Discussion, Broadcast Deregulation: The Reagan Years and Beyond, 40 ADMIN. L. REV. 345, 353 (1988) [hereinafter Broadcast Deregulation]. See also Fowler, supra note 26, at 413.

28. Straight Talk from Chairman Dingell, BROADCASTING, Feb. 16, 1987, at 31 [hereinafter Straight Talk]. See also Paul Starobin, FCC and Congress Clash Over Proper Roles, 1988 CoNG. Q. REP. 479 (Feb. 27, 1988); Edward J. Markey, Congress to Administrative Agencies: Creator, Overseer, and Partner, 1990 DUKE L.J. 967, 980-82.

29. Markey, supra note 28 , at 980 .

30. Micromanagement, supra note 11 , at 57 . 
The dispute between the FCC and the Congress, however, was not simply a question of philosophical differences. It was also a matter of turf. Fowler, Patrick, and other Reagan appointees did not consider themselves beholden to Congress. "For better for worse," as Patrick pointed out, "Congress invested in this commission a great deal of discretion to resolve public policy issues based on public input and our interpretation of the public interest." ${ }^{31}$ Congress saw the matter otherwise. Perceiving that its "policy intent was as clear as could be," oversight committee members Swift, Dingell, and Markey, as well as committee counsel Tom Cohen and Larry Irving, perceived that there was no way to "overly manage the commission"; instead, the FCC was "a renegade agency" that needed Congress to step in as an "active participant" and "bring them back." 32

The war between Congress and the FCC took place on many fields, including telecommunications policy associated with the AT\&T divestiture, the obligations of cable television to carry local programming, the proliferation of advertisements on children's programming, the drafting of rules governing network ownership of prime-time television, and a host of issues concerning the ability of the marketplace to produce balanced diverse broadcasting. ${ }^{33}$ Congress, although rarely passing new substantive legislation, successfully fought off a great number of FCC challenges to existing regulations. ${ }^{34}$ Challenges to the personal attack and political editorializing rules were abandoned, the cross-ownership prohibition was never formally challenged, and FCC rules governing telecommunications access charges as well as network ownership of prime-time television ("fin-syn") were greatly influenced by congressional signals. ${ }^{35}$ On these matters, the FCC sought to preserve some political capital with Congress by refusing to fight every possible battle to the bitter end. On other matters, meanwhile, the FCC satisfied its deregulatory appetite. It simplified the process for renewing radio and television licenses, liberalized rules governing multiple ownership of broadcast stations, eliminated the prohibition on trafficking in broadcast lines, discontinued regulation of telephone data processing services, and repealed the fairness doctrine. ${ }^{36}$

Battles between the FCC and Congress, in most respects, were not fundamentally different from other Reagan-era squabbles over deregulation. Agencies pushed their deregulatory agenda but retreated when politically

31. Starobin, supra note 28.

32. Micromanagment, supra note 11 , at 56 .

33. See Conrad, supra note 3; FREEJOHN \& SHIPAN, supra note 5; Starobin, supra note 28; Micromanagment, supra note 11 , at 56.

34. Congress, on occasion, did pass legislation. See generally Sooshan \& Krasnow, supra note 7 (discussing 1983 legislation). Most legislative efforts, however, focused on forcing the FCC to abandon or modify agency-initiated proposals. See generally Bloch, supra note 12; FREEJOHN \& SHIPAN, supra note 5 .

35. See generally Sooshan \& Krasnow, supra note 7 (access charges); Bloch, supra note 12, at 85-89 (personal attack, political editorializing, fin-syn); Conrad, supra note 3 (fin-syn); infra text accompanying notes 114-40 (cross-ownership).

36. See Broadcast Deregulation, supra note 27, at $345-48$ (introduction by Marshall V. Berger); Symposium, The FCC Under Chairman Fowler, 10 COMM/ENT L.J. 405-570 (1988). 
expedient. Congressional leadership, especially in the Democratically controlled House, screamed and shouted but rarely pursued legislative reform. Unlike analogous battles between regulators in Congress and administrative deregulators at the Department of Interior, Environmental Protection Agency, Federal Trade Commission, and elsewhere, a great many of the disputes between the FCC and Congress were inextricably linked to First and Fourteenth Amendment guarantees of a free press and equal protection of the laws. This linkage was an inevitable consequence of FCC regulations, both restricting the programming decisions of broadcasters and promoting diversity in broadcast ownership through race and gender preferences.

These constitutional concerns added a complex wrinkle to the resolution of disputes between the FCC and the Congress. FCC claims that either the First or Fourteenth Amendments prohibit broadcast regulation seem different in kind than deregulation rooted in cost-benefit analysis. Were Congress to defer to FCC constitutional interpretations, the Commission would have great incentive to cloak its deregulatory agenda in high-minded constitutional rhetoric. Needless to say, the FCC's oversight committees would concede nothing to the Commission. Instead, Congress made precisely the opposite argument, that regulation furthers constitutional values by encouraging broadcast diversity among a limited number of license holders. Nevertheless, the Commission had strong incentive to raise constitutional questions, sometimes because it served its interests in Congress and sometimes because federal court decisions would create an opportunity for the negation of disfavored regulation. The varied ways in which the Commission would raise doubts over the constitutional wisdom of broadcast regulation, and the responses of Congress and the courts to the Commission's constitutional arguments, figured prominently in defining both Commission policy and FCC-congressional relations. These complex "constitutional dialogues" lay at the heart of FCC challenges to the fairness doctrine, the cross-ownership prohibition, and diversity preferences-regulations designed to facilitate balanced and diverse broadcasting.

\section{III}

\section{THE FAIRNESS DOCTRINE}

FCC efforts to undermine the fairness doctrine both politically and constitutionally defined the competing visions of and relations between Congress and the Reagan FCC. Beginning in 1981 with bully-pulpit speeches by Mark Fowler, and ending in 1989 with the D.C. Circuit Court of Appeal's approval of the FCC's repeal of the fairness doctrine, ${ }^{37}$ this epic struggle ultimately pitted the Commission, the White House, and the federal courts against a Congress hell-bent on preserving "public trust" regulation. The battle itself, however, was

37. One of Fowler's 1981 speeches is reprinted in Fowler, supra note 26, at 445-46. The 1989 D.C. Circuit decision is Syracuse Peace Council v. FCC, 867 F.2d 654 (D.C. Cir. 1989). 
principally symbolic. Although the fairness doctrine was rarely enforced ${ }^{38}$ the fairness battle symbolized the conflict between Congress and the Commission over the propriety of broadcast regulation.

The fairness doctrine dates back to a 1929 decision by the Commission's predecessor, the Federal Radio Commission, holding that a radio station's public trustee responsibilities included an affirmative obligation to make certain that a diversity of religious, political, social, and economic viewpoints "find their way into the market of ideas." 39 This obligation of broadcasters "to encourage and implement the broadcast of all sides of controversial public issues" was formally embraced by the FCC in $1949 .^{40}$ Ten years later, Congress "statutorily approved"41 the fairness doctrine. The Congress, however, stopped short of explicitly codifying the doctrine. In enacting legislation largely concerned with preventing bona fide news events from triggering equal-time obligations, Congress included a provision stating that nothing in the amendment relieved broadcasters of their duty "to afford reasonable opportunity for the discussion of conflicting views on issues of public importance."42

Broadcasters challenged the constitutionality of government-imposed fairness obligations, arguing that growth in the number of media outlets made "public trust" regulation unnecessary, and that broadcasters should, therefore, be accorded the same First Amendment freedoms as their brethren in the print media. The Supreme Court settled this question in Red Lion Broadcasting $v$. $F C C$, a unanimous 1969 decision that not only upheld the fairness doctrine but defined the diminished constitutional freedoms of broadcasters. ${ }^{43}$ The Court, speaking through Justice White, broadly approved of the "public trustee" rationale as a justification for limited forms of content regulation, stating that " $[\mathrm{t}]$ here is nothing in the first amendment which prevents the government from requiring a licensee to share his frequency with others and to conduct himself as a proxy or fiduciary with obligations to present those views and voices which are representative of his community and which would otherwise, [due to technological limits on the number of available licenses] be barred from the airwaves." 44

38. In 1980 , for example, the FCC investigated only 28 of an estimated 20,000 fairness complaints, leading one commentator to conclude that the FCC will question the broadcaster only when the "station's position is so 'off the wall' that no reasonable person could implement it." Richard E. Labanski, May it Rest in Peace: Public Interest and Public Access in the Post-Fairness Doctrine Era, 11 COMm/ENT 219, 231 n.40 (1989). See generally id. at 230-35; Charles D. Ferris \& James A. Kirkland, Fairness-The Broadcaster's Hippocratic Oath, 34 CATH. U. L. REV. 605 (1985).

39. Mayflower Broadcasting, 3 F.R.C. Ann. Rep. 32 (1929), rev'd on other grounds, 37 F.2d 993 (D.C. Cir.), cert. denied, 281 U.S. 706 (1930).

40. Editorializing by Broadcast Licenses, 13 F.C.C. 1246 (1949).

41. That is the way the Supreme Court put it in CBS v. Democratic Nat'l Comm., 412 U.S. 94,110 n.8 (1973).

42. Pub. L. No. 86-274, \& 1, 73 Stat. 557 (codified at 47 U.S.C. $\S 315$ (a) (1982)).

43. 395 U.S. 367 (1969). Scott Powe described Red Lion as "the Supreme Court's leading decision detailing the constitutional status of broadcasting ... articulat[ing] a 'new' First Amendment, one benefitting this 'new' method of communication." LUCAS A. POWE, JR., AMERICAN BROADCASTING AND THE FIRST AMENDMENT 12 (1987).

44. Red Lion, 395 U.S. at 389. 
Red Lion, while unanimous, had two large cracks in it. First, the Court left open the door for revisiting its constitutional holding if the administration of fairness were to "reduc[e] rather than enhanc[e] the volume and quality of coverage." 45 Second, although recognizing that Congress had "ratified [the fairness doctrine] with positive legislation," Red Lion did not specify whether the FCC and courts should treat the doctrine as an administrative initiative or a statutory mandate. ${ }^{46}$

These two cracks lay at the heart of the battle over fairness. Congress thought that the doctrine was codified, and perceived that fairness and other "public trustee" regulations were necessary to combat broadcaster irresponsibility. The Commission doubted the doctrine's codification and, more significantly, thought fairness obligations counterproductive and constitutionally vulnerable. These Commission arguments challenged both Congress's political authority and the propriety of most, if not all, "public trustee" regulations. The Commission nonetheless was cautious in its challenge of fairness. The doctrine was beloved in Congress, and Red Lion's cracks could be filled by a court ruling that fairness was legislatively mandated and constitutionally sound. Fowler, realizing the risks of Congress or the courts turning back a frontal assault on fairness, ${ }^{47}$ launched a vigorous but indirect attack on the fairness doctrine.

\section{A. The FCC Challenges Fairness}

The Commission, although suggesting in September 1981 that Congress should reconsider fairness, did not formally question the doctrine until its May 1983 refusal to extend fairness to "teletext" systems. ${ }^{48}$ Teletext was a new technology which made use of the unused portions of broadcast signals to transmit text and graphics (with no sounds) on television sets through a teletext decoder. The Commission, in arguments made before the D.C. Circuit three years later, claimed that fairness did not apply because teletext more closely resembled the print media, where fairness-type obligations were clearly unconstitutional, than broadcasting, and because Congress's 1959 approval of fairness could not have extended to technologies that did not exist at that time $^{49}$ The FCC also argued that the application of fairness would not serve the public interest but, instead, would discourage the development of teletext and other new technologies. ${ }^{50}$

45. Id. at 393.

46. Id. at 381-82.

47. Telephone interview with Mark Fowler, former FCC chair (Sept. 3, 1992) [hereinafter Fowler interview].

48. Amendment to the Commission's Rules to Authorize the Transmission of Teletext, 53 Rad. Reg. 2d (P \& F) 1309 (1983) [hereinafter Teletext Order].

49. Brief for Respondents at 30, Telecommunications Research \& Action Ctr. (TRAC) v. FCC, 801 F.2d 501 (D.C. Cir. 1986) (No. 85-1160). In Miami Herald Publishing v. Tornillo, 418 U.S. 241 (1974), the Supreme Court rejected state efforts to extend fairness type obligations to the print media.

50. Teletext Order, 53 Rad. Reg. 2d (P \& F) at 1324. 
The FCC's refusal to extend fairness to new technologies was little noticed in Congress. The FCC's issuance of a May 1984 notice of inquiry to "reassess the wisdom of applying general fairness doctrine obligations to broadcast licensees" was quite another matter. ${ }^{51}$ At House and Senate oversight hearings following this FCC announcement, Fowler was warned not to "meddle in any way with" fairness or risk a "very vehement reaction from Congress." 52 "Since the beginning of your tenure," said Senator Ernest Hollings, "you have been put on notice not to weaken in any way the various political broadcasting laws or rules. So that there is no misunderstanding, the Chairman should consider such notice to be again issued." 53

Congress's admonitions were of limited value. While reaffirming the costs of an outright repeal of fairness, the Commission nonetheless persisted in its indirect attack of the doctrine. In August 1985, the Commission issued an elaborate 111 page Fairness Report condemning fairness as an "unnecessary and detrimental regulatory mechanism." ${ }^{54}$ Specifically, the Report challenged "public trustee" regulations because electronic media properties were no longer scarce. Furthermore, the FCC argued that the fairness doctrine no longer served the "public interest" because it failed in its essential purpose by actually reducing discussion of controversial issues. The Commission, accordingly, "questioned the permissibility of the doctrine as a matter of both policy and constitutional law." 55

The Commission, despite these findings, "determined that it would be inappropriate at this time to eliminate the fairness doctrine." ${ }^{\text {"6 }}$ This determination was ostensibly rooted in deference to Congress, namely the propriety of legislative resolution of the issue due to the uncertainty over whether Congress had already "mandated our retention of the fairness doctrine" caused by "the conflicting evidence found in the record" and "the intense Congressional interest in the fairness doctrine and the pendency of legislative [repeal] proposals." 57 The Commission, however, knew full well that Congress would never repeal fairness. Congressmen Dingell and Timothy Wirth (D-CO) glibly remarked in a Washington Post column that they were "consigning [the 1985 Report] to the ash-heap." 58

51. Inquiry into the General Fairness Doctrine Obligations of Broadcast Licenses, 49 Fed. Reg. 20,317 (1984).

52. Federal Communications Commission Oversight Hearings Before the Subcomm. on Telecommunications, Consumer Protection, and Finance of the House Comm. on Energy and Commerce, 98th Cong., 2d Sess. 53 (1984).

53. Reauthorization and Oversight of the FCC: Hearings Before the Subcomm. on Communications of the Senate Comm. on Commerce, Science, and Transportation, 99th Cong., 1st Sess. 3 (1985).

54. Inquiry into Section 73.1910 of the Commission's Rules and Regulations Concerning the General Fairness Obligations of Broadcast Licensees, 102 F.C.C.2d 143 (1985).

55. Id. at 246.

56. Id. at 247.

57. Id. at $246-47$.

58. John Dingell \& Timothy Wirth, The Fairness Doctrine Can Help, WASH. Post, Mar. 1, 1986, at $\mathrm{A} 21$, col. 1 . 
The FCC nevertheless launched a quiet revolution with its 1985 Report. Clearly, the political price of direct repeal was too high. The 1985 Report, however, set the stage for judicial repeal of the fairness doctrine. In its 1984 FCC v. League of Women Voters decision, the Supreme Court had indicated that it would be willing to reconsider Red Lion with "some signal from Congress or the FCC that technological developments have advanced so far that some revision of the system of broadcast regulation may be required."59 The 1985 Report paid homage to this language, quoting it to show that "the complex constitutional issues presented by the [fairness] doctrine" cannot be settled by "the mere recitation" of Red Lion. ${ }^{60}$ The Report's detailed conclusions on the "exposure growth in the communications marketplace since the inception of the fairness doctrine" sent a clear signal to the Court that it should reconsider Red Lion. ${ }^{6}$

\section{B. The D.C. Circuit Challenges the FCC}

The significance of the 1985 Report was perceived by the FCC's reviewing court, the D.C. Circuit Court of Appeals. ${ }^{62}$ In a 1986 opinion written by Judge Robert Bork reviewing the Commission's teletext ruling, the court slyly noted that "[i]n a recent study of the fairness doctrine, the FCC has attempted to get the Court to reevaluate political broadcast regulation."63 This decision, Telecommunications Research and Action Center ("TRAC") v. FCC, did not address the constitutionality of fairness. Although upholding the FCC's teletext order, the court rejected the Commission's conclusion that teletext should not be treated as a broadcast medium. Instead, the court held that the FCC was not obligated to apply fairness because Congress "never made the fairness doctrine a binding statutory obligation." 64 This bold conclusion, while not advanced by

59. 468 U.S. 364,376 n.11 (1984).

60. 102 F.C.C.2d at 153.

61. Id. at 202. See also id. at 202-21.

62. The role of the D.C. Circuit in overseeing the administrative state is chronicled in Symposium, The Contribution of the D.C. Circuit to Administrative Law, 40 ADMIN. L. REV. 507-59 (1988) [hereinafter D.C. Circuit Symposium].

The D.C. Circuit's preeminence is attributable to Congress's granting jurisdiction to the D.C. Circuit to handle challenges to FCC decisionmaking. Other appellate courts, however, are authorized to resolve disputes that originate in their circuits. Consequently, fairness doctrine proponents have sought to have other federal appellate courts reinstate the doctrine in the wake of the D.C. Circuit's validation of the FCC's repeal of fairness. See, e.g., Arkansas AFL-CIO v. FCC, No. 92-1115, vacated, 980 F.2d 1197 (8th Cir. 1993).

63. TRAC v. FCC, 801 F.2d 501, 509 n.5 (D.C. Cir.), cert. denied, 482 U.S. 919 (1986).

64. Id. at 517. This conclusion was far from inevitable. Circuit judge Abner Mikva, dissenting to a 6-5 denial of rehearing en banc, argued that Congress "explicitly approved of, ratified and codified the fairness doctrine" and criticized Judge Bork for denigrating the "primacy of Congress as policy-maker" simply because he thought the policy "in error." TRAC v. FCC, No. 85-1160, slip op. 1, 5 (D.C. Cir. Dec. 16, 1986) (Mikva, J., dissenting). Mikva's attack was prompted, in part, by Bork's comment that fairness "has come under much well-placed criticism for some time and from many quarters." TRAC, 801 F.2d at 509 n.5. 
the FCC, was certainly welcomed by the Commission. ${ }^{65}$ It paved the way for the repeal of fairness in two distinct ways. First, litigants, the Commission, or both, could claim that it would be inappropriate to enforce an administrative doctrine contrary to the public interest. Second, fairness could now be nullified on "public interest" grounds rather than on the constitutional infirmity of an act of Congress as well as a Supreme Court decision.

Direct FCC repeal of fairness remained too costly. In fact, a legislative report (practically, if not technically, binding) accompanying the FCC's fiscal year 1986 appropriations barred the Commission from eliminating or modifying fairness for that fiscal year. ${ }^{66}$ Congress's intent that the "Commission shall not change the regulations concerning the fairness doctrine" was also expressed in Congress's statutory demand that the FCC "consider alternative means of administration and enforcement of the Fairness Doctrine and report to the Congress." ${ }^{67}$ If it had ignored these pro-fairness sentiments and repealed the doctrine on its own initiative, the FCC would have flouted Congress's will and incurred severe legislative retribution.

The FCC's solution was to craft a litigation strategy so confounding, unprincipled, and politically motivated that the D.C. Circuit, in separate opinions, described it as "curious" and "puzzling." FCC, involved a broadcaster's challenge to a 1984 FCC finding that Meredith Broadcasting had violated the fairness doctrine by refusing to broadcast programming in response to a series of ads supporting construction of a nuclear power plant near Syracuse, New York. ${ }^{69}$ Meredith, not shockingly, claimed that the 1985 Fairness Report eviscerated the doctrine and, consequently, the FCC should formally repeal the doctrine and clear Meredith of any wrongdoing. The FCC opposed Meredith's claim on standing grounds. Noting that no sanctions were imposed because Meredith brought itself into compliance with the doctrine, the FCC argued that Meredith had not suffered, nor was it likely to suffer, any injury in fact from the FCC's application of fairness. ${ }^{70}$ The second case, RadioTelevision News Directors Association (" $R-T N D A$ ") v. FCC, involved arguments by a coalition of broadcasters that "in light of the Commission's [1985 Fairness Report] finding that the fairness doctrine has a chilling effect on the [F]irst [A]mendment activities of broadcasters, it is important that the Court now consider the constitutionality of the fairness doctrine." 71 The Commission,

65. See supra text accompanying notes 49-50 (describing FCC arguments in TRAC). Commission staff clearly understood TRAC to lay the groundwork for either the judicial or administrative repeal of fairness. Pitch interview, supra note 15.

66. S. REP. No. 150, 99th Cong., 1st Sess. 74 (1985).

67. The alternatives mandate can be found in 132 CONG. REC. H10619 (daily ed. Oct. 15, 1986). Congress's intent can be found in H.R. REP. No. 90-1005, 99th Cong., 2d Sess. (1986), reprinted in 132 CONG. REC. H10720 (daily ed. Oct. 15, 1986).

68. Radio-Television News Directors Ass'n ("R-TNDA”) v. FCC, 809 F.2d 860, 862 (D.C. Cir. 1987); Meredith Corp. v. FCC, 809 F.2d 863, 868 n.3 (D.C. Cir. 1987).

69. 99 F.C.C.2d 1389 (1984).

70. Respondent's Brief at 13-18, Meredith, No. 85-1723.

71. $R-T N D A, 809$ F.2d at 862 . 
while refusing to repeal fairness on its own initiative, heartily endorsed this effort to compel judicial eradication of the doctrine. Noting that the doctrine "generally aggrieves all broadcasters as well as not serving the public interest," the Commission opposed intervenor efforts to dismiss the case on jurisdictional grounds. $^{\text {2 }}$

The logic of the Commission's curious posturing was purely political. As the FCC's general counsel, Jack Smith, noted at oral argument in Meredith, "we are not talking law school enforcement, legal textbook arguments; we're talking political reality here." 73 In other words, as the D.C. Circuit observed in its Meredith opinion, "[i]t is patently obvious that because of non-legislative expressions of congressional concern, the Commission does not wish to weaken enforcement of the fairness doctrine-at least in the absence of a judicial opinion that directs that course."74 Since Meredith's claim was that the Commission should itself repeal fairness, the FCC argued that Meredith had no standing. That, in the Commission's words, "Meredith makes a persuasive case that the Fairness Doctrine generally aggrieves broadcasters based on serious constitutional questions raised by its operation" was irrelevant; no standing, after all, was no standing. ${ }^{75}$ Conversely, since the broadcaster's association sought judicial invalidation of fairness, the Commission supported court action.

The D.C. Circuit would have none of these political shenanigans. In $R$ $T N D A$, the court agreed with the intervenors' claim that the 1985 Report did not constitute agency action subject to direct challenge in the D.C. Circuit and, accordingly, dismissed this claim for lack of jurisdiction. ${ }^{76}$ In Meredith, the court ruled that Meredith "unquestionably ha[d] standing" since the FCC's fairness finding could be used against Meredith in a license renewal hearing." More significantly, the Meredith court took the Commission to task. Writing for the court, Judge Laurence Silberman first blithely observed that the Commission must not have believed fairness was codified when it issued its 1985 Report; "otherwise, it would have been irresponsible for the Commission gratuitously to cast constitutional doubt on a congressional command."78 Judge Silberman then attacked the Commission for its political cowardice, observing that "we are aware of no precedent that permits a federal agency to ignore a constitutional challenge to the application of its own policy merely because the resolution would be

72. Respondent's Brief at 17, Meredith, No. 85-1723 (discussing FCC's position in R-TNDA). In R-TNDA, the Commission characterized its 1985 Report as "a final action to which the Commission does not intend to return in the foreseeable future." Brief for FCC on Jurisdiction at 6, R-TNDA No.85-1691. For further discussion, see Bloch supra note 12, at 126 n.270.

73. Meredith, 809 F.2d at 873.

74. Id. (emphasis added).

75. Respondent's Brief at 23, Meredith, No. 85-1723 (emphasis supplied).

76. 809 F.2d 860, 862-63 (D.C. Cir. 1987). For additional discussion of $R$-TNDA, see Bloch, supra note 12 , at $134 \mathrm{n} .285$.

77. Meredith, 809 F.2d at 869.

78. Id. at 872 . 
politically awkward."79 Accordingly, the Commission was instructed to consider, on remand, Meredith's constitutional arguments.

The FCC may not have asked for the Meredith remand, but they very much welcomed it. With the court order that the FCC resolve constitutional challenges to fairness, the Commission told Congress that it was forced to definitively resolve Meredith's fairness challenge. ${ }^{80}$ The Commission could not hide its anxiousness to settle the fairness issue. It instituted a rulemaking proceeding to consider the Meredith remand on January 23, 1987, despite the fact that the D.C. Circuit had not yet considered a request for a rehearing en banc. ${ }^{81}$ Ironically, the very next month, the FCC also began work on its congressionally assigned task of exploring alternatives to the fairness doctrine. ${ }^{82}$

\section{The Congress Challenges the FCC}

The D.C. Circuit's remand of Meredith was a stinging defeat for fairness proponents. The 1985 Fairness Report left little doubt as to what the FCC would do in its remand proceeding. Backed into a corner, Congress was forced to either statutorily mandate or abandon fairness. Congress chose the former tack. First, to stall the FCC's repeal of fairness and, thereby, buy the Congress time to codify the doctrine, the FCC's House oversight committee wrung a promise from FCC Chair Fowler that "we will not decide the Meredith case before we bring in our [fairness alternatives] report to the Congress." ${ }^{83}$ Second, free-standing legislation to codify the doctrine, the Fairness in Broadcasting Act, was put on the legislative "fast track"-introduction in March, hearings in April, completion of House and Senate committee action in May, approval in both houses of Congress and presentment to the President in June. ${ }^{84}$

Congress framed its efforts here in terms of good public policy and the reaffirmation of legislative control over broadcasting. Senate Commerce Chair Hollings, when introducing the measure, spoke of the FCC's "astounding," "relentless and misguided vendetta against the Fairness Doctrine." ${ }^{85}$ House Commerce Chair Dingell was even more blunt in attacking the FCC for "tak[ing] a provision that has been settled for many years and simply proceed[ing] to

79. Id. at 874 .

80. See Honeymoon Over; Impending FCC Action on Fairness Irks Congress, 7 COMM. DAILY 147, July 31, 1987, at 1 [hereinafter Honeymoon Over].

81. The Commission rulemaking was initiated on January 23,1987 , one week after the Meredith decision. Order Requesting Comment, 2 F.C.C.R. 794 (1987). As Senator Hollings observed, "the FCC was under no mandate of the court to begin its inquiry in such a short time. In fact, the Meredith decision [was] not even effective." 133 CONG. REC. S3130 (daily ed. Mar. 12, 1987).

82. Report of the Commission, 2 F.C.C.R. 5272 (1987).

83. Honeymoon Over, supra note 80.

84. For stories on Congress's consideration and approval of this legislation, see Senate Approves Bill to Codify FCC's Faimess Doctrine, BNA Daily Rpt. for Exec., April 22, 1987 at A-3; House Energy and Commerce Committee Approves Legislation to Codify FCC's Fairness Doctrine, BNA Daily Rpt. for Exec., May 14, 1987, at A-1; Fairness Doctrine on its Way to White House, BROADCASTING, June 8, 1987, at 33.

85. 133 CONG. REC. S3130 (daily ed. Mar. 12, 1987) (statement of Sen. Hollings). 
disregard it without any cogent or visible reason ...."86 Dingell warned that "that kind of action carries with it certain real perils," for "Congress is a very large and immensely powerful, rather slow moving, but absolutely irresistible body when it finally starts moving." 87 These comments reveal that congressional leadership perceived its institutional prestige to be on the line in the battle over fairness.

These concerns of power overshadowed Congress's assessment of both the constitutional appropriateness of "public trustee" regulations on broadcast speech and the continued viability of Red Lion's constitutional analysis. At the same time, congressional hearings and member statements at conference and on the floor took issue with the Commission's conclusion that fairness squelched the presentation of diverse perspectives of controversial issues and, therefore, no longer served the public interest. "Without the fairness doctrine," as Chairman Dingell put it, "discussion of public affairs could become either one-sided or be reduced to a bland, uniform pablum as broadcasters react to economic pressures from commercial advertisers ...." Consequently, emphasizing that "the public interest standard established in the context of broadcasting means that broadcasters are public trustees with unique responsibilities," 89 Congress overwhelmingly approved of fairness legislation (59-31 in the Senate; 302-102 in the House). Congress's unwavering, unquestioning support of Red Lion made clear that Capitol Hill took as a given what the FCC's marketplace approach towards the First Amendment hotly disputed. For Congress, broadcasters are not part of the First Amendment press; broadcasters, instead, are subject to regulations, including content-based restrictions, which are believed to serve, though not proven to serve, the "public interest."

Congress's willingness to put the Commission in its place through fairness legislation did not end the issue, however. White House acquiescence was also necessary. President Reagan, however, strongly opposed fairness and unhesitatingly followed a Department of Justice recommendation that he veto the fairness bill as "antagonistic to the freedom of expression guaranteed by the First Amendment." $"{ }^{\circ}$ Reagan's veto message flatly rejected public trustee regulations in favor of full First Amendment rights for broadcasters. "In any other medium besides broadcasting," Reagan contended, "such federal policing of the editorial

86. Straight Talk, supra note 28 , at 33 .

87. Id.

88. Codification of Fairness Doctrine Appears Imminent, BroADCASTING, April 13, 1987, at 78.

89. Fairness in Broadcasting Act of 1987: Hearings on S. 742 before the Subcomm. on Communications of the Senate Comm. on Commerce, Science, and Transportation, 100th Cong., 1st Sess. 17 (1987) (statement of former FCC chair Charles D. Ferris).

90. Veto of Fairness in Broadcasting Act of 1987, 23 WeEKLY COMP. PRES. DOC. 715 (June 29, 1987) [hereinafter Veto message]. This message is in accord with the Justice Department's conclusion that fairness frustrates the "purpose of the First Amendment," namely, "to help assure that the people are adequately informed about public issues, not to assure they are adequately informed by one particular medium or group of media." Justice's View on the Fairness Doctrine Bill, BROADCASTING, Apr. 27, 1987, at 33 . 
judgment of journalists would be unthinkable."91 The President's veto did not catch Congress by surprise; the strength of his anti-fairness convictions did. A former broadcaster, Reagan described radio as "an effective, efficient medium that has adapted to changes in society and technology," "earning my living exercising my First Amendment rights." Following the veto (and Congress's inability to launch a serious override effort), fairness proponents sought to snatch victory from the jaws of defeat by including the fairness doctrine within a $\$ 600$ billion catch-all spending bill for fiscal year $1988 .^{94}$ Reagan, however, stood firm. He conditioned his signing of the spending bill on Congress's exclusion of fairness. ${ }^{95}$ Congress, to the chagrin of fairness supporters, blinked, and future codification efforts never got off the ground during the Reagan and Bush Administrations. ${ }^{96}$

\section{The FCC Repeals Fairness}

The writing of the fairness doctrine repeal was certainly on the wall during the fight between Congress and the White House over the 1987 Fairness in Broadcasting Act. One month after the President's successful veto of that bill, on August 4, 1987, the FCC (with Dennis Patrick now at the helm) ended what little suspense remained by voting unanimously to abolish the fairness doctrine. The Commission, reaffirming its 1985 Fairness Report, judged the doctrine to be unconstitutional and opposed to the public interest. ${ }^{97}$

The Commission's opinion, while expected, held a few surprises. Unlike the 1985 Report, which was formally limited to the public interest issue, the 1987 repeal was framed in constitutional terms. This finding went beyond the Meredith remand which noted that "the Commission need not confront [the constitutional] issue" if it finds the doctrine "contrary to the public interest." 98 The Commission reached out to decide the constitutional issue for strategic reasons. Knowing that its repeal would be challenged in court, the Commission wanted to set the stage for a court ruling that fairness was unconstitutional. ${ }^{99}$

91. Veto message, supra note 90.

92. Ronald Reagan, A Presidential Perspective on Radio, BroadCasting, Sept. 8, 1986, at 22.

93. The President vs. the Fairness Doctrine, BROADCASTING, June 29, 1987, at 29.

94. See "The Rise and Fall of the Fairness Doctrine," Part III: The President Stands Firm, BroadCasting, Dec. 28, 1987 at 31.

95. See id.; Neal Devins, Appropriations Redux: A Critical Look at the Fiscal Year 1988 Continuing Resolution, 1988 DUKE L.J. 389, 398.

96. Energy Commerce Chair Dingell reintroduced fairness legislation in 1989. Although originally included in the fiscal year 1990 appropriations package, the provision was unceremoniously dropped in bill negotiations. See Jackie Calmes, Bush, Congress Reach Deal on Deficit-Reduction Bill, 47 CONG. Q. WKLY. Nov. 25, 1989, at 3221. With Clinton in the White House, Congress may well reenact the faimess doctrine. The Fairness in Broadcasting Act was introduced in the Senate on February 4, 1993 and in the House on May 5, 1993. The fairness doctrine was also folded into campaign reform legislation approved by the Senate on June 30, 1993. See Bill Holland, FCC Rules on Share Data; Fairness Doctrine on Hold, BILlBOARD, July 31, 1993, at 66.

97. In re Complaint of Syracuse Peace Council Against WTVH, 2 F.C.C.R. 5043 (1987).

98. Meredith Corporation v. FCC, 809 F.2d 863, 874.

99. Pitch interview, supra note 15; Fowler interview, supra note 47. 
Indeed, to make it impossible for a court to extricate the Commission's public interest determination from its constitutional analysis, Commission General Counsel Diane Killory argued "that any policy justifications are so intertwined with constitutional implications that we cannot separate the two."100 Such a constitutional ruling would foreclose legislative reform and, equally important, drive a stake into the heart of public trustee regulations.

The 1987 repeal was also surprising because it contained a vitriolic attack of Justice White's Red Lion decision. The Commission was not content to challenge the factual predicates of spectrum scarcity and broadcaster diversity which underlay Red Lion. Although making that argument, the heart of the fairness repeal was a frontal assault on Red Lion's public trustee-rooted differentiation of the print and broadcast press's First Amendment rights. For the Commission, " $[t]$ he reasons for proscribing government intrusion into the editorial discretion of print journalists provide the same basis for proscribing such interference into the editorial discretion of broadcast journalists. The First Amendment was adopted to protect the people."101

The fairness repeal, without more, would have triggered a ferocious legislative panning of the Commission. In addition to the repeal, the Commission, contrary to its stated understanding with Congress, did not release its congressionally mandated study of alternatives to fairness prior to its resolution of the Meredith remand. Instead, on the day it repealed fairness, it issued its alternatives report, informing Congress that no fairness alternative "is preferable to eliminating [the] doctrine entirely." 102 Congress's response to the Commission's willingness to couple insult with injury was a tirade of unsurpassed venom. The Commission's timing was labelled tricky "in the Nixonian sense," "a thinly veiled attempt to end-run Congress." 103 The Commission's decision on fairness was characterized as "wrongheaded, misguided, and illogical," "unconscionable," "craven," "a plain and simple outrage," "pure nonsense," and "crap." 104 Finally, relations between Congress and the Commission had deteriorated into "crisis," with the FCC being labelled as "untrustworthy," "totally out of control," and "lickspittles."105

100. Fight with Congress Assumed; FCC Declares Fairness Doctrine Unconstitutional, COMM. DAILY, Aug. 5, 1987, at 1 .

101. Syracuse Peace Council, 2 F.C.C.R. at 5057.

102. Inquiry into Section 73.1910 of the Commission's Rules and Regulations Concerning Alternatives to the General Fairness Doctrine Obligations of Broadcast Licensees, 2 F.C.C.R. 5272 (1987).

103. Eleanor Randolph, FCC Scraps "Fairness Doctrine"; Angry Hill Chairmen Consider Response, WASH. Post, Aug. 5, 1987, at A-1; Bob Davis, FCC Abolishes Fairness Doctrine, Arousing Debate, WALL ST. J., Aug. 5, 1987, at 8, col. 3.

104. These legislator quotes can be found in The Good, the Bad, and the Ugly, BroadCASTING, Aug. 10, 1987, at 59; Tom Shales, The FCC, On the Attack, Against Fairness, WASH. POST, Aug. 5, 1987, at C-1; Swift Disputes View; Dennis Tells Fate of Fairness Doctrine Rests on Industry Performance, СОМм. DAILY, Sept. 22, 1987, at 3.

105. These legislator quotes can be found in, The Good, the Bad, and the Ugly, supra note 104; Shales, supra note 104; Broadcast Bill Ready, Comm. DAILY, Sept. 24, 1987, at 4. 
The FCC's repeal received a better reception in court. Seeking to kill fairness now and forever, the Commission asked the court of appeals to invalidate fairness on both constitutional and public interest grounds. ${ }^{106}$ In Syracuse Peace Council v. FCC, the court granted half of this request, approving the Commission repeal on public interest grounds without considering the constitutional question. ${ }^{107}$ That Meredith explicitly invited the Commission to live up to its oath to "defend the Constitution" by passing on the constitutionality of fairness was now irrelevant. Noting that "American courts are not to pass upon a constitutional question ... if there is also some other ground upon which the case may be disposed of," the court "[h]appily" ducked the constitutional question. ${ }^{108}$ Under this approach, fairness was indeed repealed but Red Lion remained intact, as did Congress's ability to statutorily mandate fairness. ${ }^{109}$ Moreover, this ruling did not call into question the Commission's power to administratively reinstate fairness.

\section{E. Summary}

The repeal of the fairness doctrine was the result not of a bold regulatory agency initiative, but of a series of complex political and judicial interactions. Only the wildest speculation on the part of the Commission could have predicted the outcome of the series of court decisions, legislative initiatives, and White House responses. The FCC, however, deserves extraordinary credit (or blame) for pushing the repeal of fairness while simultaneously seeking to avoid a headon confrontation with Congress. In the end, this dual pursuit proved impossible. Congress would not let the FCC have it both ways. For the FCC, once it released the 1985 Fairness Report, a chain of events outside its control had been triggered and there was no going back.

The role of constitutional interpretation in these fairness wars is rather peculiar. The Constitution seemed at once central and ancillary to the resolution of this dispute. The FCC was rather selective in its invocation of the Constitution. Prior to its repeal of fairness, the FCC spoke only of "constitutional doubts" in its 1985 Fairness Report and D.C. Circuit arguments. This

106. Pitch interview supra note 15. See also Respondent's Brief, Syracuse Peace Council v. FCC, 867 F.2d 654 (D.C. Cir. 1989), cert. denied, 493 U.S. 1019 (1990) (No. 87-1516).

107. Syracuse Peace Council, 867 F.2d at 657.

108. Id. at 657, 659. Judge-and later Bush Solicitor General-Kenneth Starr would have reached the constitutional issue because "the agency was examining the faimess doctrine's lawfulness through First Amendment lenses." Id. at 674 (Starr, J., concurring).

109. The Solicitor General and FCC claimed that the possibility of legislative restoration of fairness made it unnecessary for the Supreme Court to review Syracuse Peace Council. "[T] properly presented are narrow-whether the Communications Act compels the Commission to apply the fairness doctrine"; a question that could be nullified by the enactment of pending legislation. Brief for the Federal Respondents in Opposition at 12-13, Syracuse Peace Council v. FCC, 493 U.S. 1019 (1990) (No. 85-1516). Although suggesting that Congress could reimpose faimess, the Commission was correct in opposing certiorari. Since it was unlikely that the Supreme Court would transform a narrow "public interest" holding into a broad constitutional pronouncement, the Commission had nothing to gain through Court review. 
constitutional hesitancy, of course, was a function of politics. The FCC and its Chair, Mark Fowler, while opposing fairness, sought an appropriate vehicle for the repeal of fairness with some degree of trepidation. ${ }^{110}$ The FCC's solution was for the D.C. Circuit to do the Commission's constitutional dirty work for it. While that tactic did not fully succeed, the Meredith remand created the appropriate setting for the FCC's repeal of fairness. ${ }^{111}$ Once the Commission was set to cross that abyss, it proved quite able to launch a full throttle constitutional attack on fairness. And why not? The constitutional argument was a powerful one, which, with some luck, might be ratified by the D.C. Circuit.

The approaches of Congress and the White House to the constitutional issue were more straightforward. The White House chose not to be an active player in the administration of fairness or other FCC regulatory doctrines. While the White House sometimes "jawbones" administrative agencies, ${ }^{112}$ the Reagan White House, while making critical appointments decisions, rarely involved itself in FCC matters. Its involvement, instead, was limited to signing off or vetoing legislative action. On fairness, the President fought off legislative efforts on First Amendment grounds. Congress's involvement was far more pervasive but not very complex. Congress was concerned with power, not the Constitution. The FCC's attack on fairness challenged Congress's domain in two ways. First, the repeal effort was considered a disrespectful end-run around legislative prerogatives. Second, the substance of the challenge called into question the appropriateness of "public trustee" regulations of broadcasting. The House and Senate Commerce Committees, while they could not escape the constitutional dimensions of this challenge, paid attention to the Constitution only so much as was necessary to uphold its prerogatives. As it turns out, that was not too often. For the most part, FCC oversight committees referred to the "public interest," not the Constitution.

The last player in this drama, the courts, were somewhat inconsistent in their invocations of the Constitution. R-TNDA declined to consider the constitutionality of fairness for jurisdictional reasons; Meredith refused to resolve the constitutional issue itself, but encouraged the Commission to consider the constitutionality of fairness on remand; Syracuse Peace Council refused to rule on the constitutional question because of the availability of alternative grounds.

110. Telephone interview with Bruce Fein, FCC General Counsel under Fowler (May 4, 1990); Pitch interview, supra note 15.

111. In repealing fairness, the Commission placed great emphasis on the D.C. Circuit's rulings in $T R A C$ and Meredith. For the Commission: "[W]ith the uncertainty of the doctrine's codification removed [in TRAC], and the Meredith court's directive to consider the constitutional issues, we believe it is now incumbent upon us to consider the doctrine in terms of the inextricable constitutional issues upon which the policy rests." In re Complaint of Syracuse Peace Council against WTVH, 2 F.C.C.R. at 5062 n.62 (1987). This leveraging of court decisions makes clear that the Commission did not "orphan" its repeal efforts in the face of legislative opposition. For a competing perspective, see Bloch, supra note 12 , at 59-84.

112. See Paul R. Verkuil, Jawboning Administrative Agencies: Ex Parte Contacts by the White House, 80 COLUM. L. REV. 943 (1980). 
The courts prompted the Commission's constitutional holding while refusing to speak to the issue themselves.

The irony of this battle over fairness is that after years of administrative, judicial, and legislative conflict, the doctrine may well reemerge. Indeed, separate versions of the Fairness in Broadcasting Act of 1993 have been introduced in the House and Senate. ${ }^{113}$ The lesson here is simple but profound. Without the court's backing its claim that the Fairness Doctrine was unconstitutional, the FCC's administrative constitutional interpretation is as politically vulnerable as public interest findings. The Fowler and Patrick FCCs then accomplished very little by invoking the Constitution. Had Syracuse Peace Council upheld their conclusions on the (un)constitutional status of fairness, however, the FCC would have made policy more binding than legislation. That policy, of course, would have limited the reach of FCC authority. For deregulators, however, the more confining the judiciary, the better the judiciary.

\section{IV}

\section{INTERLUDE: RUPERT MURDOCH V. CONGRESS}

The battle over fairness was emblematic of other disputes between the FCC and Congress, with the Commission bowing to marketplace deregulation and the Congress sticking to public trustee regulation. One of these disputes involved 1975 Commission regulations prohibiting the concurrent ownership of a newspaper and television station in the same market, regulations rooted in "the assumption that there is a correlation between additional voices and greater diversity."114 The context of this dispute was an ongoing feud between Rupert Murdoch and congressional leadership, during which Murdoch convinced the Commission to temporarily waive the cross-ownership ban and, in turn, the Congress passed legislation prohibiting the FCC from extending Murdoch's temporary waiver.

The events began in 1978 with the Supreme Court's approval of the crossownership ban in FCC v. National Citizens Commission for Broadcasting. ${ }^{15}$ Rejecting First Amendment objections by broadcasters and publishers, the Court reaffirmed the "fundamental principle" laid down in Red Lion that there is no "unbridgeable First Amendment right to broadcast comparable to the right of every individual to speak, write, or publish."116 Due to the Fowler Commission's attack on Red Lion and concomitant commitment to broadcasters' "press" rights, the cross-ownership ban seemed an inevitable target of FCC "unregulation."

113. See supra note 96 .

114. Brief for the FCC at 20, FCC v. National Citizens Comm'n for Broadcasting, 436 U.S. 775 (1978) (No. 76-1471).

115. 436 U.S. 775 (1978).

116. Id. at 799 (quoting Red Lion Broadcasting Co. v. FCC, 395 U.S. 367, 388 (1969)). 
Of course, Congress was intensely interested in prohibiting cross-ownership. In July 1985, hearings were held to "underline, underscore, and emphasize to people the importance of concentration and cross-ownership."117 Later that year, language was included in a conference report and a letter was sent to the FCC by its oversight committee "that the cross-ownership rules are vitally important" and that the Commission should review "with greater scrutiny" requests for waivers to the cross-ownership ban. ${ }^{118}$ The Commission, up to a point, heeded these concerns. It elected to put off any challenge to the crossownership rule unless the fairness doctrine was set for repeal. The FCC nonetheless persisted in granting temporary waivers to cross-ownership. Several of these waivers were granted to Rupert Murdoch.

Congress liked neither the FCC's willingness to grant temporary waivers nor Rupert Murdoch. Murdoch, an Australian media mogul who apparently became a U.S. citizen in order to satisfy federal requirements governing his purchase of television stations in New York, Boston, and elsewhere, was described on the Senate floor as "the No. 1 dirt bag owner of any publications or electronic media in this nation," as "someone who arrived here from Australia ... and goes around trying to get us to change the rules," and as a "sneaky operat[ive]."119 Congress's distaste for Murdoch was a byproduct of the hatchet job his papers, The New York Post and The Boston Herald, had done to Senator Edward Kennedy (describing the Senator as immoral, overweight, and floundering), Senator Earnest Hollings, and other congressional leaders. The FCC, for its part, gleefully granted temporary waivers to Murdoch's New York and Boston operations. ${ }^{120}$ Congress, "acute[ly] aware of the[se] requests of $\mathrm{Mr}$. Murdoch," 121 blew its cool when, in late 1987, the Commission questioned whether the cross-ownership ban served the public interest and instituted a Notice of Proposed Rulemaking to reexamine the ban. ${ }^{122}$ Following on the heels of the fairness veto, Congress correctly concluded that the FCC was positioning itself to extend its fairness repeal to cross-ownership. ${ }^{123}$

117. Media Mergers and Takeovers: The FCC and the Public Interest, Hearings before the Subcomm. on Telecommunications, Consumer Protection and Finance of the House Comm. on Energy and Commerce, 99th Cong., 1st Sess. (1985), reprinted in part in 134 CONG. REC. S65 (daily ed. Jan. 26, 1988) (statement of Rep. Wirth).

118. Letter from House of Representatives, Subcommittee on Telecommunications, Consumer Protection and Finance of the Committee on Energy and Commerce, to Mark S. Fowler (Nov. 13, 1985) [H.R. No. 453, 99th Cong., 1st Sess. 433 (1985)], reprinted in 134 CONG. REC. S65 (daily ed. Jan. 26, 1988).

119. 134 Cong REC. S142 (daily ed. Jan. 27, 1988) (statement of Sen. Weicker); Id. at S141 (statement of Sen. Wirth); 134 CONG. REC. S59 (daily ed. Jan. 26, 1988) (statement of Sen. Hollings).

120. According to one account: "[Mark Fowler] said at his retirement party: 'The greatest gift I gave to anybody as Chairman of the FCC was an 18-month waiver to Rupert Murdoch.' And everybody clapped and said "Whoopee." 134 CONG. REC. S58 (daily ed. Jan. 26, 1988) (statement of Sen. Hollings).

121. 134 Cong. Rec. S141 (daily ed. Jan. 27, 1988) (statement of Sen. Wirth).

122. Amendment of Section 73.3555 of the Commission's Rules, the Broadcast Multiple Ownership Rules, 2 F.C.C.R. 1138 (1987).

123. Telephone interview with Michael Carvin, former Reagan Justice Department official and plaintiff's counsel in Lamprecht (Aug. 27, 1992) [hereinafter Carvin interview]. See also News America 
Congress struck back at both Murdoch and the Commission. It enacted a limitation rider for fiscal year 1988 prohibiting the FCC "to repeal, to retroactively apply changes in, or to begin or continue a re-examination of ... or to extend the time period of current grants of temporary waivers to" the crossownership ban. ${ }^{124}$ The rider, for one year at least, killed the FCC re-examination. The rider also blocked the FCC from extending Murdoch's temporary waivers in Boston and New York, both due to expire in the 1988 fiscal year. Since no other temporary waivers were due to expire in 1988, Murdoch was the only person adversely affected by this proviso.

The rider was at once a political masterstroke and an outrage. Fearing a veto threat because of Reagan's strong opposition to the cross-ownership ban, ${ }^{125}$ the rider was quietly inserted at conference by Senators Kennedy and Hollings into the massive fiscal year 1988 spending bill only hours before the 471 page bill was submitted to the Congress for an immediate vote. Its existence was known to members of the FCC's oversight committees and few others. The President, who signed the bill only after pushing out the fairness doctrine, did not know of its existence. Indeed, the "discovery" of the cross-ownership rider did not take place until several days after enactment. ${ }^{126}$

Congressional leadership embraced the rider, salvaging some small victory after their biting defeat over fairness. In Senate debates subsequent to the enactment of this "sneak attack" limitation rider, Senator Kennedy proclaimed "our unsatisfactory experience with the FCC and the repeal of the fairness doctrine" makes the cross-ownership ban's "emphasis on diversity ... more important than ever."127 Senator Hollings, in defending his rider spoke in impassioned tones about his oversight Committee's "struggl[e]" with a "runaway animal in the FCC," "an administrative arm of the U.S. Congress," which has nonetheless declared "open season ... in getting rid of nearly any kind of rule and regulation." ${ }^{28}$ For Senator Hollings, the cross-ownership rider was reflective of a larger congressional effort to "take [this] administrative body and bring them in line" through limitation riders prohibiting the FCC's reconsideration of favored congressional policies. ${ }^{129}$ The supporters of the rider also defended the prohibition on extensions of Murdoch's temporary waivers. Admitting that the resolution was "aimed directly" at Murdoch "to insure ...

Publishing, Inc. v. FCC, 844 F.2d 800 (D.C. Cir. 1987) (describing FCC reaction to Murdoch litigation). 124. Act of Dec. 22, 1987, Pub. L. No. 100-202, 101 Stat. 1329 (1987). For a discussion of the statutory interpretation issues raised by this rider, see Devins, supra note 95, at 414-21.

125. See Paul Pien \& Steven Goodman, Deflecting a "Laser Beam" from Murdoch, LEGAL TIMES, May 16, 1988, at 17.

126. News America Publishing, Inc. v. FCC, 844 F.2d 800, 807 (D.C. Cir. 1988). Accord Devins, supra note 95 , at 419.

127. 134 CONG. REC. S143 (daily ed. Jan. 27, 1988) (statement of Sen. Kennedy).

128. 134 CONG. REC. S56 (daily ed. Jan. 26, 1988) (statement of Sen. Hollings).

129. Id. at S57-58. 
that he wasn't going to abuse the process anymore,"130 Senator Kennedy nevertheless characterized the rider as a neutral measure designed to prevent anyone from evading the cross-ownership rule by "obtaining a permanent exemption in the guise of a series of temporary waivers."131 He claimed, "Diversity is the issue .... What [Murdoch] has done is reduce diversity."132

Rupert Murdoch, burned by the Congress, did what any naturalized U.S. Citizen would do-he sued. In News America Publishing, Inc. v. FCC, a divided D.C. Circuit Court of Appeals agreed with Murdoch's First Amendment challenge to the rider. ${ }^{133}$ Emphasizing that "only" Murdoch could not "seek an extension during the fiscal year," 134 the court concluded that the noextensions rider poorly served Congress's purported goal of preserving the crossownership prohibition. Instead, to protect the cross-ownership rule, the court opined that the FCC should treat initial grants of temporary extensions and extension renewals alike.

The News America case was revealing on several fronts. At one level, there were strong parallels to fairness. The FCC, which disliked both the Murdoch and cross-ownership reconsideration riders, hoped that the D.C. Circuit would strike a blow to cross-ownership. ${ }^{135}$ In contrast to the fairness debate, however, the FCC had little latitude to question the riders. By statutorily directing the FCC not to extend temporary waivers, Congress technically compelled the Commission to defend Murdoch's challenge. ${ }^{136}$ Perceiving itself a prisoner of war forced to denounce its homeland, the Commission's solution to this dilemma

130. Reply Brief for Appellant at 3-4, News America Publishing, Inc. v. FCC, 844 F.2d 800 (D.C. Cir. 1988) (No. 88-1037); Jerry Williams, Sen. Kennedy Clash on Radio, BosTON HERALD, Jan. 8, 1988, at 59.

131. 134 CONG. REC. S59 (daily ed. Jan. 26, 1988) (statement of Sen. Kennedy).

132. Id.

133. 844 F.2d 800 (D.C. Cir. 1987).

134. Id. at 814 .

135. See infra notes $139-140$ and accompanying text. See also Diane S. Killory \& Richard J. Bozelli, Book Review, 40 FED. COM. B.J. 413, 415-16 n.8 (1988); Samuel A. Simon \& David Wagenhauser, Can Rupert Murdoch Have it all; Media Cross-Ownership Rules, 246 NATION 181 (Feb. 13, 1988). The prohibition on the FCC's reexamination of the cross-ownership rule was not directly at issue in News America. Murdoch's challenge was limited to the temporary extension prohibition. The FCC, however, obliquely noted in its brief that "[t]he number of media outlets available to a viewer in a given market might well be a relevant factor in a reevaluation of whether the cross-ownership rule continues to be necessary to further the public interest, if the Commission were able and willing to undertake such a reevaluation." Corrected Brief for the FCC at 21 n.6, News America Publishing, Inc. v. FCC, 844 F.2d 800 (D.C. Cir. 1988) (No. 88-1037). At oral argument, moreover, Judge Laurence Silberman (who ordered the FCC in Meredith to assess the constitutionality of fairness) expressed doubt about the constitutionality of cross-ownership.

136. Independent agencies perceive that it is politically incumbent upon them to defend legislative mandates. Telephone interview with Diane Killory, FCC General Counsel under Patrick (Sept. 10, 1992) [hereinafter Killory interview]. The D.C. Circuit also speaks of the "well known principle that regulatory agencies are not free to declare an act of Congress unconstitutional." Meredith, 809 F.2d at 872 . Nevertheless, during the News America litigation, some political appointees within the Commission hoped that the Department of Justice-pursuant to the president's power to "take care" that the laws are faithfully executed-would have insisted that the FCC refuse to defend the Murdoch rider. See generally Note, The Authority of Administrative Agencies to Consider the Constitutionality of Congressional Statutes, 90 HARV. L. REV. 1682 (1977). 
was to offer a weak defense to the temporary extension rider at issue in News America. The Commission's brief conceded that the statute was sustainable only under rational basis scrutiny because "Congress might have been able to pass a bill that better addressed its fears," "premised" its defense of the rider "on the assumption that the rider was not impermissibly focused on [Murdoch,]" and "acknowledged that the legislative history contains conflicting statements" on this question. ${ }^{137}$ When News America was decided in March 1988, the Commission "applauded" its defeat. "The Court by this decision," FCC Chair Dennis Patrick said, "has demonstrated that the Congress does not have a free hand in the regulation of the broadcast press." 138

News America, like the fairness debate, also highlighted the crucial role played by the D.C. Circuit in this area. The conclusion that the temporary extension rider was purposefully limited to Murdoch was debatable; appropriations riders are necessarily limited to a single fiscal year making Murdoch "a legitimate class of one" subject to Congress's broader concern of foreclosing repeated temporary extensions. ${ }^{139}$ Comments by rider sponsors, admittedly, cast doubt on this assertion; the choice, however, was for the D.C. Circuit to make. That it chose to strike down an arguably constitutional act of Congress provides a glimpse into its self-designated status as a player in administrative policymaking. ${ }^{140}$

The epilogue to the News America decision also distinguishes cross-ownership from fairness. On cross-ownership, Congress lost this skirmish but won the larger battle. Murdoch sold his papers rather than prolong his personal war. The FCC elected not to prolong its battle over cross-ownership in subsequent fiscal years.

\section{$\mathrm{V}$ \\ RED Lion ReduX: The FCC'S Failed Challenge to RaCE PREFERENCES}

The power of the judiciary and the executive to settle constitutional disputes between the Congress and the FCC was again evidenced in FCC efforts to examine the constitutional propriety of race and other preferences. Unlike fairness, where the courts and the White House prompted and protected FCC repeal efforts, the judiciary and the executive ultimately weighed in on the side of race preferences. Left on its own, the FCC could not overcome congressional support for race preferences.

137. Corrected Brief, supra note 135, at 32, 33, 43. Fearing such a slip shod defense of the rider, House leadership directed the General Counsel to the Clerk, Steven R. Ross, to file a brief defending the Murdoch rider. News America, 844 F.2d at 801.

138. Communications, FCC Applauds Federal Court Decision Striking Down Cross-Ownership Law, BNA Daily Rept. for Execs., Mar. 31, 1988.

139. This was the view of Judge Spottswood Robinson, who dissented in News America. See also Devins supra note 95 , at 414-21.

140. See D.C. Circuit Symposium, supra note 62. 
The story of FCC race preferences was far more complicated, and far more bizarre than the above snapshot suggests. While Congress's support for race preferences did not waiver, the courts, the executive, and the FCC each flipflopped so much on this question that it was impossible to know what was up and what was down until the Supreme Court's 1991 affirmation of FCC race preferences in Metro Broadcasting Inc. v. FCC-a case, incidentally, whose precedental future is clouded in uncertainty. ${ }^{141}$ The only way to unscramble this story is to pay attention to politics and personalities, not constitutional interpretation.

\section{A. Background: The Rise of Diversity Preferences}

The source of the FCC's preference was neither the Congress, the Commission, nor the White House. Rather, the D.C. Circuit ordered the FCC to provide a comparative preference to racial minorities in order to serve program diversity objectives. Perceiving that "minority ownership is likely to increase diversity of content," the race preference was deemed integral to the FCC's responsibility to promote the "public interest" through its awarding of broadcast licenses. ${ }^{142}$ The D.C. Circuit Court's 1973 decision, TV 9 Inc. v. FCC, was an appeal of the FCC's refusal to value minority status in according a broadcast license. The Nixon Commission's position was that "the Communications Act, like the Constitution, is color blind. What the Communications Act demands is service to the public ... . and that factor alone must control the licensing processes, not the race, color or creed of an applicant."143 In other words, the FCC rejected the minority ownership-diversity programming nexus in 1973.

Through a certiorari petition filed by Solicitor General Robert Bork, the FCC sought Supreme Court review of TV 9. Despite FCC claims that minority preferences "raise the most serious constitutional questions" and that the appellate court improperly substituted its judgment for that of the Commission, ${ }^{144}$ the Supreme Court refused to hear the case. ${ }^{145}$ The Commission accordingly instructed its administrative law judges to afford comparative merit to applicants when minority owners were to participate in the operation of the station.

Program diversity was the exclusive concern of the D.C. Circuit in TV $9 .{ }^{146}$ In 1977, however, reports prepared for the FCC Conference on Minority

141. 497 U.S. 547 (1990). For my overview and criticism of Metro Broadcasting, see Neal Devins, Metro Broadcasting, Inc. v. FCC: Requiem for a Heavyweight, 69 TEX. L. REV. 125 (1990). As to Metro's clouded future, see infra, part V, notes 209-28.

142. TV 9, Inc. v. FCC, 495 F.2d 929, 938 (D.C. Cir. 1973), cert. denied, 419 U.S. 986 (1974).

143. Mid-Florida Television Corp., 33 F.C.C.2d 1, 17 (1972).

144. Petition of the United States for a Writ of Certiorari at 17, Federal Communications Comm'n v. TV 9, 419 U.S. 986 (1974).

145. 419 U.S. $986(1974)$.

146. Remedial concerns did, however, play a role in the case when it was before the Commission. Commissioner Benjamin Hooks advocated a comparative preference to "redress[ ] past injustices." MidFlorida Television Corp., 37 F.C.C.2d 559, 560 (1972). 
Ownership revealed that a "systematic series of barriers imped[ed] minority ownership," including FCC broadcast allocation policies that effectively favored nonminority concerns. ${ }^{147}$ In 1978, an FCC Taskforce Report found "the underrepresentation of minorities in the ownership of broadcast stations" to be "a direct result of the general societal discrimination." 148

President Carter echoed his appointees' concerns, pointing to "discrimination and exclusion in the past" as largely responsible for minority underrepresentation in broadcasting. ${ }^{149}$ For the White House, the TV 9 comparative hearing preference was not enough. It successfully lobbied the FCC both to provide tax breaks to broadcasters who sold their stations to minority owners and to allow broadcasters, whose qualifications had been called into question and otherwise could not sell their stations, to sell their licenses at "distress sale" prices to FCCapproved minority enterprises. ${ }^{150}$ While the stated purpose of these May 1978 regulations was "to provide a more diverse selection of programming,"151 the Carter FCC preference appeared to be a merger of remedial and diversity concerns. Specifically, because the underrepresentation of minority owners was attributable to societal discrimination, the FCC had to remedy that discrimination to achieve program diversity.

The constitutionality of race preferences was never seriously considered in either the D.C. Circuit's establishment of the comparative preference in $T V 9$ or in the White House-prodded FCC extension of race preferences in 1978. TV 9 simply noted that the FCC may advance the public interest by "consider[ing] factors which do not find expression in constitutional law." 152 "Inconsistency with the Constitution," the court proclaimed without further elaboration, "is not to be found in a view of our developing national life which accords merit to Black [applicants]." ${ }^{153}$ The Carter proposal and FCC policy statement did not even pay lip service to the Constitution. The absence of any reference to equal protection concerns is striking, for the Supreme Court's consideration of Board of Regents of the University of California v. Baake had sparked a heated national debate on the constitutionality of affirmative action. ${ }^{154}$

Congress seemed equally uninterested in the Constitution when it enacted legislation in 1981 authorizing the FCC to grant licenses through a lottery. In

147. Bari S. Robinson, Achieving Diversity in Media Ownership: Bakke and the FCC, 67 CAL. L. REV. 231 (1979).

148. MINORITY OWNERSHIP TASKFORCE, FEDERAL COMMUNICATIONS COMM'N, MinORITY OWNERSHIP IN BROADCASTING 7 (1978).

149. Telecommunications Minority Assistance Program, 1980-81 PUB. PAPERS 1703, 1704 (Pres. Carter). See also Telecommunication Minority Assistance Program, 1977-78 PUB. PAPERS 252 (Pres. Carter).

150. Statement of Policy on Minority Ownership of Broadcast Facilities, 68 F.C.C.2d 979, 981 (1978).

151. Id.

152. TV 9, 495 F.2d at 936.

153. Id.

154. 438 U.S. 265 (1978). Baake was decided in June 1978, one month after the issuance of FCC diversity regulations. The constitutional status of diversity preferences therefore was uncertain at the time the FCC issued its 1978 Statement. 
order to encourage broadcast diversity through inclusion of a variety of underrepresented groups, including labor unions and community organizations as well as women and minorities, the legislation required the FCC to grant these groups significant preferences. ${ }^{155}$ That profound First Amendment, due process, and equal protection concerns were raised by this enactment did not trouble Congress. ${ }^{156}$ In conference, the lottery provision was added to a catch-all spending bill without any consideration of these constitutional concerns.

The 1981 FCC (chaired by Mark Fowler) refused to implement the statute, in part, because of these constitutional concerns. Although supportive of lottery legislation, the Commission perceived that Congress, not just the Commission, must find that minorities and women have suffered from discrimination. ${ }^{157}$ Congress quickly and without acrimony responded to these constitutional concerns. Knowing that the Commission supported the lottery legislation, Congress viewed the FCC's concerns as legitimate and not a constitutional smoke screen. A second lottery statute was enacted in 1982, which, like the Local Public Works Act set-aside approved in Fullilove v. Klutznick, limited the diversity preferences to "Blacks, Hispanics, American Indians, Alaska Natives, Asians, and Pacific Islanders." ${ }^{158}$ Furthermore, the conference report accompanying the bill specified that the racial designation was responsive to the conferees' finding "that the effects of past inequities stemming from racial and ethnic discrimination have resulted in a severe underrepresentation of minorities in the media of mass communications . ..."159 The dropping of the gender designation was not explained, although the conferees cryptically noted that women, labor unions, etc., would receive a preference "if they meet the eligibility guidelines." 160

Congress and the Commission worked in tandem on the question of race preferences until 1985. Tax certificate and distress sale initiatives were extended in 1982 to limited partnerships. ${ }^{161}$ Moreover, the Commission endorsed the 1982 lottery statute, although Fowler cautioned that " $[\mathrm{t}] \mathrm{o}$ diverge from a norm of color blindness is to foster racial antagonism and to denigrate individual liberty."162 Finally, and most surprising, FCC regulations implementing the 1984 Cable Communication Act reinstated, despite constitutional objections

155. Omnibus Budget Reconciliation Act of 1981, Pub. L. No. 97-35, 95 Stat. 357, 736-37 (1982).

156. These were the conclusions reached by the FCC in its assessment of the statute. See In The Matter of Amendment of Part 1 of the Commission's Rules to Allow the Selection From Among Mutually Exclusive Competing Applications Using Random Selection or Lotteries Instead of Comparative Hearings, 86 F.C.C.2d 257, 276-77 (1982).

157. Id. at 281.

158. Communications Amendments Act of 1982, Pub. L. No. 97-259 §§ 115(c)(1)-(2), 96 Stat. 1087 , 1094 (1983).

159. H.R. REP. No. 765, 97th Cong., 2d Sess. 43 (1982), reprinted in 1982 U.S.C.C.A.N. $2261,2287$.

160. Id. at 2289.

161. FCC News Release, Rpt. No. 5112, FCC Acts to Increase Minority Participation in Telecommunications Field, Dec. 3, 1982.

162. In the Matter of Amendment of the Commission's Rules to Allow the Selection From Among Certain Competing Applications Under Random Selection or Lotteries Instead of Comparative Hearings, 93 F.C.C.2d 952, 1020 (1983). 
raised by the Department of Justice, affirmative action demands that had earlier been dropped in conference in order to secure Republican Senate leadership support. ${ }^{163}$

\section{B. From Steele to Bush}

Commission support for diversity preferences underwent a sea change in 1984. The triggering event was a challenge to the FCC's awarding of comparative gender preferences, a practice that began in 1978 when the Commission's Review Board concluded that TV 9's emphasis on diversity of viewpoint based on group status extended to gender as well as race. ${ }^{164}$ The gender preference scheme was never formally endorsed and not especially beloved, and the FCC proved it an ineffective defense in Steele v. FCC. The Commission's brief cited but never discussed studies of stereotypical portrayals of women in the broadcast media; noted that women were "significantly underrepresented in their ownership of telecommunication facilities" but did not refer to a 1982 study highlighting female underrepresentation; discussed this 1982 study to explain the "potential for abuse" in gender preferences because many "female owners of TV stations are the wives of other station owners"; and distinguished race from gender preferences because "women have not been excluded from 'the mainstream of society' to the same extent as racial and ethnic minorities."165

The Commission, in short, failed to make a convincing case for the necessity of a gender preference to allow grossly underrepresented female broadcasters to counteract the negative stereotyping of women perpetuated by the maledominated media. The FCC, instead, argued that it was "rational for the Commission to conclude that the increased participation of women ... would enhance diversity of viewpoint and diversification of ownership." 166 This defense was inadequate to the task and a divided panel of the D.C. Circuit invalidated the gender preference. ${ }^{167}$ Chastising the Commission for its "questionable" and "offensive" "presumption" that more women broadcasters would increase program diversity without "offer[ing] any evidence other than statistical underrepresentation," Judges Edward Tamm and Antonin Scalia depicted the gender preference as an "experiment in social engineering conceived seemingly by whim and rationalized by conclusive dicta." 168

163. See Leigh Hermance, Comment, Constitutionality of Affirmative Action Regulation Imposed Under the Cable Communications Policy Act of 1984, 35 CATH. U. L. REV. 807, 820-28 (1986).

164. Gainesville Media, Inc., 70 F.C.C.2d 143 (1978).

165. This is the view of former FCC Commissioner Glenn Robinson as well as Mark Fowler's chief of staff Peter Pitch. Telephone interview with Glenn Robinson (Aug. 20,1992) [hereinafter Robinson interview]; Pitch interview, supra note 15. This conclusion is corroborated by the failure of either the FCC or Congress to respond to the D.C. Circuit's 1992 invalidation of gender preferences. See infra notes 219-28 and accompanying text.

166. Brief for Appellee at 21 n.10, 22-23, Steele v. FCC, 770 F.2d 1192 (D.C. Cir. 1985) (No. 841176). A far more aggressive defense of gender preferences was launched by the Bush FCC in Lamprecht v. FCC, 958 F.2d 382 (D.C. Cir. 1992). See infra note 216 and accompanying text.

167. Steele v. FCC, 770 F.2d 1192 (D.C. Cir. 1985).

168. Id. at 1199 . 
It is difficult to know whether the Steele brief was purposefully ineffective. What is clear is that the Commission was poised to rescind its awarding of race and gender preferences in broadcast licensing. That is the inescapable conclusion of the Commission's surprising response to the D.C. Circuit's en banc vacating of the panel decision in Steele. In vacating Steele on its own initiative and requesting that the FCC file a supplemental brief on the constitutionality of the gender preference, the D.C. Circuit invited the FCC to defend the preference before a more sympathetic en banc hearing. ${ }^{169}$ The Commission, in September 1986, declined this invitation; it simultaneously filed both a brief contending that its "current policy of granting race and gender preferences conflicts with constitutional standards" and a motion to remand so that it could determine whether it could establish a nexus between the preference scheme and enhanced diversity above and beyond the "diversity of programming and viewpoint" produced by "market forces."

The Commission's assertion that it "closely examined the [race and gender] preference scheme, pursuant to the Court's request, and concluded that it fails to pass constitutional muster as a tool to enhance diversity"171 enraged Congress. Within one month of the Commission's remand request, and one week of the court's granting that request, all five Commissioners and their general counsel were the subject of "rather unpleasant" ${ }^{172}$ hearings. Congressman John Bryant (D-TX) characterized it as "almost pointless" to work with the Commission; Congressman Mickey Leland (D-TX) referred to the need to draft "FCC proof" legislation as well as the need to "fight this Commission tooth and nail" on civil rights; and Congressman Edward Markey (D-MA) labelled the reexamination "a cloudburst in a storm of suspicion and distrust which seems to hover over this Commission." 173

The Commission's efforts to justify the Steele remand by claiming "to be bound by the Constitution" and the corresponding necessity "to visit upon the American people ... an analytically sound decision" 174 were flatly rejected as "legalistic gobbledy gook," "a lot of esoteric, intellectual, whatchamacallit."175 "That legal stuff invades my intelligence," said Leland, who claimed instead, that the FCC has a "responsibility to the humanity of all citizens of this country." 176 The Congress, with a distaste for the Commission's legalistic arguments, accused

169. Order, Steele v. FCC, No. 84-1176 (D.C. Cir., Nov. 23, 1985) reprinted in Minority-Owned Broadcast Stations: Hearings on the H.R. 5373 Before the Subcomm. on Telecommunications, Consumer Protection, and Finance of the House Comm. on Energy and Commerce, 99th Cong., 2d Sess. 85 (1986) [hereinafter Steele Hearings].

170. Brief for Federal Communications Commission on Rehearing En Banc at 22-23, Steele v. FCC, 770 F.2d 1192 (D.C. Cir. 1985). See id. at Appendix (motion for remand).

171. Id. at 19 (emphasis added).

172. Killory interview, supra note 136.

173. Steele Hearings, supra note 169, at 31, 20, 22.

174. Id. at 36 (testimony of FCC chair Fowler), 39 (testimony of FCC Commissioner Patricia Diaz Dennis).

175. Id. at 55 (statement of Rep. Swift), 39 (statement of Rep. Leland).

176. Id. 
the FCC of hiding behind adverse court rulings of its own making. Congressman Allen Swift (D-WA), pointing to FCC action on fairness, cable "must carry" rules, and diversity, stated, "I simply do not understand how the FCC can go into court and fail to present the best possible argument. ... It seems to me that if you don't like these policies, you should have the guts to change them ... and you should send lawyers down to court who will defend them-not take dives." 17

The failure of the FCC to defend its preference scheme when invited to do so by the en banc panel in Steele, as well as the FCC's decision to reconsider its comparative race preference scheme in the context of a gender preference challenge, leaves little doubt that the Commission sought to transform the Steele dismissal into a principled justification for a complete reexamination of all diversity preferences. ${ }^{178}$ Indeed, to preempt a possible D.C. Circuit ruling upholding diversity preferences, the FCC also sought remand of a related challenge to the race-specific distress sale policy. Angry members of the House Energy and Commerce Committee responded to this action by writing to the Commission that " $[\mathrm{g}]$ iven that Congress has found a 'nexus' does exist, the FCC is not free to represent to the court that such a finding has not been made, or that [the] agency's findings are anything other than views that are superseded by the findings of Congress." 179

The FCC was oblivious to these congressional demands disguised as ruminations. Already at war with the Congress over fairness, the FCC perceived that it had little political capital to lose by going forward with its market-oriented challenge to diversity preferences. On December 30 , the Commission launched a full-blown inquiry into the sensibility of all diversity preferences on both constitutional and public policy grounds. ${ }^{180}$ Like the Fairness Report, this inquiry would have provided the empirical foundations for the Commission's final action on diversity. Also, as in the fairness debate, the constitutional and policy questions were linked. Unless the preferences served diversity, the preferences failed under both public interest and constitutional criteria. ${ }^{181}$ Finally, as with fairness, the Commission seemed prepared to engage in factfinding that would undercut Congress's findings. Indeed, the Commission's notice of inquiry specifically requested comments on "whether [the FCC] is bound by, or may rely on, congressional findings of constitutionality until

177. Id. at 54 (statement of Rep. Swift).

178. This was certainly the view of FCC critics. See id. at 70-83 (written FCC responses to oversight committee questions); Tyrone Brown, The FCC's New Threat to Minority Preferences, WASH. POST, Sept. 26, 1986, at A-27.

179. Quoted in "A Shameful Thing"; NMBC Pledges to Keep Minority Preferences in FCC Rules, COMM. DAILY, Oct. 28, 1986, at 4.

180. In the Matter of Reexamination of the Commission's Comparative Licensing, Distress Sales and Tax Certificates Policies Premised on Racial, Ethnic or Gender Classifications, F.C.C.R. 1316 (Dec. 30, 1986).

181. Id. at 1317-18. 
directed otherwise by a court, or whether it must independently assess the constitutional issues." 182

The FCC's direct attack on legislative factfinding was too much for Congress. Senator Lautenberg (D-NJ), in introducing legislation to codify diversity preferences, complained that "[t]he FCC seems to think that it can put itself above the Congress and above the courts." ${ }^{83}$ Rather than enacting this legislation, however, Congress settled on a limitation rider prohibiting the expenditure of funds "to repeal, to retroactively apply changes in, or to ... continue a reexamination of the rules of the Federal Communications Commission" regarding expanding minority and women ownership of broadcasting licenses. ${ }^{184}$ The Senate report accompanying this rider noted that the FCC reexamination was "unwarranted" and that the Congress "has found that promoting diversity of ownership of broadcast properties satisfies important public policy goals." 185

President Reagan did not blink when he signed this provision as part of the 1987 catch-all spending bill. Although the President had earlier threatened to veto that bill if it contained fairness provisions, the White House was not at all exercised over race and gender preferences. That Reagan signed the FCC funding ban should come as no surprise. The gains from vetoing the funding ban were few and the costs enormous. ${ }^{186}$ Unlike fairness, the broadcasting industry did not oppose the preferences. The funding ban, moreover, was a one year measure that might be judicially struck down as a result of ongoing constitutional challenges. With no apparent gains, there was little incentive for the President to wage war with powerful civil rights interests. This is especially true since Ronald Reagan did not philosophically oppose race preferences as he did content restrictions on broadcasters. Despite all of his campaign rhetoric, Reagan did little to stand in the way of affirmative action. ${ }^{187}$ Granted, his Justice Department vigorously opposed race preferences; however, outside of court, the Administration left in place several of its predecessor's most controversial programs and policies. The Administration, moreover, was outspoken in its support of set-aside programs designed to increase minority business ownership. ${ }^{188}$

182. Id. at 1318 .

183. 133 CONG. REC. S5494 (daily ed. Apr. 24, 1987) (statement of Sen. Lautenberg).

184. Continuing Appropriations, FCC Salaries and Expenses, P.L. No. 100-202, 101 Stat. 1329-32 (1987).

185. S. REP. No. 182, 100th Cong., 1st Sess. 76 (1987). The Senate Report also "instruct[ed] the Commission" to defend race preferences in several pending D.C. Circuit cases. Id. at 77.

186. Fein interview, supra note 25. Interview with Toni Cook, Staff Members-Communications, Senate Commerce, Science \& Transportation Committee (June 2, 1992) (hereinafter Cook interview).

187. See Jeremy Rabkin, Reagan's Secret Quotas, New RePublic, Aug. 5, 1985, at 55; Herman

BelZ, EQuAlity TRANSFORMED: A QuARTER-CENTURY OF AFFIRMATIVE ACTION (1991); Chester

E. Finn, Jr., "Affirmative Action" Under Reagan, COMMENTARY, April 1982, at 17.

188. See Neal Devins, Affirmative Action After Reagan, 68 TEX. L. REV. 353 (1989). See also sources supra note 187. 
The FCC funding ban, while drafted by the Congress and approved by the President, did not, of course, foreclose judicial review of the diversity preferences. By forbidding FCC reexamination of the diversity preference, however, the rider forced the Reagan FCC, under Patrick, to defend the Carter-era initiatives. The FCC did so, portraying the program as an appropriate mechanism to advance First Amendment diversity concerns. The FCC declined to make the argument that the preference could also be supported as a remedial measure. Instead, the Commission maintained that its "goal in implementing the preferences policy has not been to remedy discrimination against minorities or to provide remedial benefits." 189 The commission was not bothered that its eschewing of remedial concerns made its argument constitutionally suspect; the rider did not mandate that diversity preferences be defended "at all costs."190 With the election of George Bush, however, the FCC once again changed its position on race preferences. President Bush, seeking to normalize relations between the FCC and Congress, distanced himself from the Reagan Administration. His three FCC appointees, Alfred Sikes, Sherrie Marshall and Andrew Barnett, all expressly supported the use of preferences in the awarding of broadcast licenses during their confirmation hearings. ${ }^{191}$ Before the Supreme Court, moreover, the Commission argued that diversity preferences served "the compelling governmental interests of promoting diversity in broadcast programming and remedying discrimination." 192

\section{The Metro Broadcasting Decision}

The constitutionality of the FCC's awarding of distress sale and comparative hearing preferences to racial minorities ultimately made its way to the Supreme Court in Metro Broadcasting, Inc. v. FCC. ${ }^{193}$ Before the Court, the Congress, the FCC, and the Department of Justice ("DOJ") each offered their competing institutional perspectives. Distrustful of FCC representation, the Congress, through the Senate's Office of Legal Counsel, separately argued that the preferences were legislatively mandated and intended "to overcome past inequities and to advance a legitimate public interest in diversity of programming." 194 The FCC advanced identical arguments. However, the Bush DOJ opposed the FCC in Metro Broadcasting. Characterizing the diversity preference as "precisely the type of racial stereotyping that is anathema to basic constitu-

189. Brief for the FCC, Winter Park Communications v. FCC, 873 F.2d 347 (D.C. Cir. 1989) (No. 85-1755).

190. Pitch interview, supra note 15.

191. See Nominations-July: Hearings Before the Comm. on Commerce, Science, and Transportation, U.S. Senate, 101st Cong., 1st Sess. 1, 341 (1989) (statement of Alfred C. Sikes); id. at 365 (statement of Andrew Barrett); id. at 380 (statement of Sherrie Marshall).

192. Brief for Federal Communications Commission at 27, Metro Broadcasting, Inc. v. FCC, 497 U.S. 547 (1990) (No. 89-453).

193. 497 U.S. 547 (1990).

194. Brief for the U.S. Senate as Amicus Curiae at 2, Metro Broadcasting, Inc. v. FCC, 497 U.S. 547 (1990) (No. 89-453). 
tional principles," the DOJ's arguments in Metro were indistinguishable from Reagan Administration attacks on race preferences. ${ }^{195}$ Nonetheless, rather than exercise his power as sole government litigator before the Supreme Court in FCC licensing cases, Bush's Solicitor General Kenneth Starr allowed the FCC to serve as the government's principal voice in the case. ${ }^{196}$

Why the Bush administration, through the DOJ and the FCC, presented conflicting arguments before the Supreme Court is unclear. One explanation is that the President was caught between a rock and a hard place. On the one hand, his desire to stabilize FCC-Congress relations necessitated formal FCC support for the program. On the other hand, his ostensible opposition to race preferences also demanded a formal repudiation of the program.

By a five-to-four vote, the Supreme Court sided with the Congress and the Commission, upholding FCC race preferences in Metro Broadcasting. In approving these programs, the Court did not demand a finding that the preferences would remedy particularized discrimination by the FCC. The Court, moreover, did not think it significant that the preferences were responsive to societal discrimination which limited opportunities for minority broadcasters. Concluding that deference was owed Congress's employment of race because of its "institutional competence as the national legislature," Metro Broadcasting found it unnecessary to employ a remedial constraint. ${ }^{197}$ Instead, the Court held that "benign race-conscious measures mandated by Congress-even if those measures are not 'remedial' . . - - are constitutionally permissible to the extent that they serve important governmental objectives within the power of Congress and are substantially related to the achievement of those objectives." ${ }^{198}$

Under this standard of review, the Court had little difficulty upholding the FCC plan. First, although the funding ban did not statutorily mandate diversity preferences, the Court concluded that Congress "has made clear its view that minority ownership policies advance the goal of diverse programming."199 Second, referring to a slew of cases upholding FCC regulation of broadcasters to ensure the "widest possible dissemination of information from diverse and antagonistic sources," the Court found broadcast diversity "at the very least" an important governmental objective. ${ }^{200}$ Third, although neither Congress nor the FCC ever sought to prove the nexus between minority ownership and diversity broadcasting, the Court noted that "[w]ith respect to this 'complex' empirical

195. Brief for the United States as Amicus Curiae at 9, Ashroline Communications Co. v. Shuberg Broadcasting of Hartford, Inc., 497 U.S. 547 (1990) (No. 89-453).

196. For an analysis of Solicitor General-FCC relations in Metro Broadcasting, see Neal Devins, Unitariness and Independence: Solicitor General Control of Independent Agency Litigation, _ CAL. L. REV. [forthcoming publication on file with author].

197. Metro Broadcasting, Inc. v. FCC, 497 U.S. 547, 563 (1990).

198. Id. at 563-64.

199. Id. at 571.

200. Id. at 569 . 
question, we are required to give 'great weight to the decisions of Congress and the experience of the Commission." 201

The Metro Broadcasting Court's approval of the FCC preference shocked the Congress, the Commission, and the Solicitor General's office. ${ }^{202}$ After the Court's 1989 Richmond v. Croson ${ }^{203}$ decision, there was reason to think that a firm conservative majority dominated the Court on the race preference issue. $^{204}$ The real surprise of Metro Broadcasting, however, was not its outcome. Prior cases amply supported the federal government's use of race to remedy societal discrimination. ${ }^{205}$ Accordingly, the FCC and the U.S. Senate, in briefs filed before the Court, characterized the preference as a congressionally mandated remedy. ${ }^{206}$ The Court did not travel this paved road. Instead, it elected to make the focus of its inquiry the nonremedial objective of promoting program diversity through increasing minority ownership.

The key to this mystery is Justice Byron White. White, who had earlier demanded that race preference programs both satisfy strict scrutiny review and remedy proven discrimination, provided the critical fifth vote in Metro Broadcasting. ${ }^{207}$ White, however, was also the author of Red Lion and held strong beliefs about the continued correctness of that decision. Whether White was personally offended by FCC efforts to publicly repudiate one of his most important decisions is unknown. What is known is that White hinged his Metro Broadcasting vote on the Court's adoption of a diversity rationale. According to Justice William Brennan's personal records and conversations between Brennan and his biographer Stephen Wermiel, White refused to sign onto a Brennan-drafted opinion upholding the preferences on remedial grounds and insisted that the majority base its opinion on Red Lion's endorsement of diversity-based broadcast regulation. ${ }^{208}$

201. Id. at 570.

202. Cook interview (Congress) supra note 186; Killory interview (FCC), supra note 136; Telephone interview with Tom Merrill, former Deputy Solicitor General (Aug. 20, 1992).

203. City of Richmond v. J.A. Croson Co., 488 U.S. 469 (1989).

204. See Devins supra note 188 , at 360 .

205. See Fullilove v. Klutznick, 448 U.S. 448, 476-78 (1980) (upholding a remedial set-aside enacted by Congress); Croson, 488 U.S. 480, at 484 (discussing and distinguishing Fullilove from set-asides enacted by state and local government).

206. Brief of the U.S. Senate, supra note 194, at 2 ("The interest of the Senate in this case is grounded in the conviction that the legislation [that] Congress has enacted to required the continuation of the FCC's policy is a measured and constitutional effort to overcome past inequities and to advance the legitimate public interest in diversity of programming.") (emphasis added); Brief for Federal Communications Commission at 16, Metro Broadcasting, Inc. v. FCC, 497 U.S. 547 (1990) (No. 89-453) ("The minority enhancement and other statutory policies that seek to further minority ownership of broadcast stations should also be viewed as an effort by Congress to remedy the effects of past discrimination.") (emphasis added). The Red Lion issue, despite its obvious relevance to diversity preference, caught everyone by surprise. In its brief opposing diversity preferences, the Solicitor General refers only once to Red Lion in the wake of the FCC's fairness repeal. Brief for the United States, supra note 195 , at 31 ("It is thus far from clear that the interest in promoting 'program diversity' is sufficiently compelling to justify the use of racial classifications.").

207. White, for example, endorsed strict review in Croson, 488 U.S. 469 (1989).

208. Telephone interview with Stephen Wermiel (Oct. 20, 1992). 


\section{Summary}

Metro Broadcasting's approval of the FCC preferences was a dramatic chapter in a twenty-five-year story of confrontational and often acrimonious exchanges between the courts, the Congress, the White House, and the FCC. Metro also reveals that the courts played the dominant role in this drama: first by ordering race preferences in $T V 9$, next by raising doubts about the FCC preferences in Steele, and finally by reaffirming the FCC preferences in Metro.

The FCC certainly recognized this judicial role. Rather than question the constitutionality of preferences on its own initiative, the FCC waited for some judicial signal. Once that signal was delivered, the Fowler FCC tried to replicate its fairness strategy to strike down the preferences. Unlike fairness, however, Congress enacted a limitation rider which preempted FCC factfinding and forced the FCC to defend the preferences in court. The key to this legislative victory was the Reagan White House's willingness to approve preferences. Clearly, had the White House opposed preferences with the same vehemence that it opposed fairness, the FCC would have been able to administratively repeal the preference program by dispelling the presumption that race preferences provide greater program diversity than unregulated market forces.

The FCC's unwillingness to advance its constitutional claims without the shibboleth of a court mandate proved its undoing. Congress was able to launch an effective counteroffensive before the FCC could accomplish its desired objective. Congress's counterattack also reveals that the legislature was disinterested in the "gobbledy gook" of constitutional arguments. Although rightly distrusting the FCC, Congress had no interest in assessing the race preference-broadcast diversity nexus and, with it, the constitutional soundness of the diversity program. Congress's sole concern was protecting a program it supported and reasserting its power over the FCC.

The saga of FCC race preferences again reveals that constitutional interpretation often runs a poor second to political reality. The FCC was circumspect in its invocation of the Constitution. The Congress seemed unconcerned with the Constitution. The Reagan and Bush White Houses offered conflicting constitutional messages-arguing against preferences in court while supporting preferences through legislation and administrative appointments.

\section{VI}

\section{Finale: Judge Thomas and Gender Preferences}

The most surprising chapter in FCC-congressional relations is the demise of gender preferences in the granting of broadcast licenses. Following Metro Broadcasting, the fate of gender preferences seemed secure. Congressional action preserving FCC race preferences, so important to Metro's validation of race preferences, applied with equal force to gender preferences. Moreover, Bush's FCC appointees accepted gender preferences and would rather have defended these preferences than do battle with Congress over them. In the topsy-turvy world of communications policymaking, however, things do not play 
out according to Hoyle. The wild card here was a renegade panel of the D.C. Circuit which placed gender preferences outside the reach of Metro Broadcasting.

The pivotal player in this episode was Clarence Thomas. On February 19, 1992, Associate Justice Thomas returned to the D.C. Circuit to issue his most controversial appellate court decision, Lamprecht $v$ FCC. ${ }^{209}$ Argued in January 1991, Lamprecht played a significant part in the Thomas confirmation hearings. Following the Senate Judiciary Committee's substantive questioning of Thomas, a September 30, 1991 Legal Times story reported that Thomas's stated willingness to live with Metro Broadcasting was misleading because he had drafted an opinion invalidating FCC gender preferences. ${ }^{210}$ When Lamprecht was issued, according to D.C. Circuit Judge James Buckley, it "demonstrate[d] the general accuracy of the information divulged to The Legal Times."211

Lamprecht struck down the gender preference because the FCC, both in its brief and at oral argument, failed to support its predictive judgment that a nexus exists between female ownership and program diversity. ${ }^{212}$ Furthermore, the only study "either inside or outside the legislative record" revealed that "women are just one and one quarter times [125\%] as likely [as men] to broadcast women's programming."213 That report's conclusion that "women station ownership result[s] in a greater degree of minority programming" did not matter. ${ }^{214}$ Likewise, it did not matter that D.C. Circuit Judge Abner Mikva found the degree of correlation more than sufficient to support the preference, stating, "[T] he line that we draw is neither more nor less principled than the line that he draws; our lines are merely grounded in a different exercise of judgment." 215

Lamprecht was truly remarkable. It took aim at the FCC, the Congress, and Metro Broadcasting. FCC efforts to defend the gender preference by pointing to Metro Broadcasting, Congress's affirmation of the ownership-broadcast diversity nexus, Civil Rights Commission reports on sex stereotyping in broadcasting, and FCC studies on the underrepresentation of women broadcasters were rejected out of hand. ${ }^{216}$ Instead, Lamprecht chided Congress for prohibiting the Commission from assessing the validity of the presumed

209. 958 F.2d 382 (D.C. Cir. 1992).

210. Specter Questioned Thomas about Metro, LEGAL TIMES, Sept. 30, 1991, at 20.

211. 958 F.2d at 403 (Buckley, concurring). Several members of Congress concurred in Buckley's assessment and used Lamprecht to question Justice Thomas's integrity.

212. $958 \mathrm{~F} .2 \mathrm{~d}$ at 395 .

213. Id. at 396, 397. That study was a 1988 Congressional Research Service Report, Minority Broadcast Station Ownership and Broadcast Programming: Is There a Nexus?

214. Congressional Research Service Report, supra note 213, at cover page. D.C. Circuit Judge Abner Mikva, dissenting in Lamprecht, cited this CRS Report language. 958 F.2d at 412 (Mikva, dissenting).

215. Lamprecht, 958 F.2d at 398 n.9.

216. Brief for the FCC at 34-41, Lamprecht v. FCC, 958 F.2d 382 (D.C. Cir. 1992) (No. 88-1395). The FCC was far more forceful in its advancement of gender preferences in Lamprecht that in Steele. See supra text accompanying note 168 . Lamprecht did not cite evidence calling into question the propriety of gender preferences; Lamprecht discussed at length evidence of female underrepresentation and sex-stereotyping in broadcasting. 
ownership-diversity nexus in its reexamination of race and gender preferences. ${ }^{217}$ The Supreme Court was also not immune from Lamprecht (perhaps because its author, who technically sat on both the D.C. Circuit and the Supreme Court when the opinion was issued, recognized that the Metro decision's precedental force was limited by his presence on the Court). Rather than reassert the Metro decision's emphasis on the "overriding significance" of congressional action and findings, Lamprecht cited out of context language in Metro that courts ought not to "'defer to the judgment of Congress and the Commission on a constitutional question.",218

Lamprecht's demand that the diversity nexus must stand on hard evidence and not presumptive analysis was not unreasonable, but it was at odds with Metro. With Congress and the FCC ostensibly behind the preference, a Supreme Court appeal and nexus-affirming factfinding at both the Commission and the Congress certainly seemed in order. Lamprecht, however, remains intact. No judicial, administrative, or legislative efforts have been launched to restore gender preferences. The explanation is that gender preferences lack a powerful proponent. While neither Congress nor the Commission would repeal these preferences, there is little interest in fighting for their reinstatement in the face of an adverse court ruling.

The source of the gender preference, a 1978 FCC review board decision, was never ratified by the Commission; instead, the Commission ruled that women should receive a downgraded comparative hearing preference. ${ }^{219}$ The Commission, moreover, refused to extend distress sale and tax certificate preferences to women, concluding that they have not suffered discrimination "of the same order" as racial minorities. ${ }^{220}$ Commission complacency as to the plight of female underrepresentation was also revealed in FCC opposition to legislatively specified gender preferences in the first lottery statute. In direct contradiction to its diversity-based comparative hearing preference, the FCC attacked the validity of gender preferences "not enacted as compensation for past discrimination." 221 After Congress dropped the gender specification in its second lottery

217. Lamprecht, 958 F.2d at 385. It did not matter that Congress's foreclosing of the FCC's reexamination was rooted in the purported belief that "[d]iversity of ownership results in diversity of programming and improved service to minority and women audiences." Id. at 391 .

218. Lamprecht, 958 F.2d at 391 (quoting Metro Broadcasting, Inc. v. FCC, 497 U.S. 547, 570 (1990)). In Metro, the Court deemphasized its reviewing role by setting against the language cited in Lamprecht the "great weight" owed and the "close attention" that must be given to Congress and FCC "expertise" on the nexus issue. 497 U.S. at 570 . Lamprecht, instead, sets off its recognition that "great weight" be given to the decisions of Congress and the FCC with the admonition that the courts cannot shirk their reviewing role. 958 F.2d at 391 .

219. The review board decision is Gainesville Media Inc., 70 F.C.C.2d 143 (1978). The relative downgrading of gender preferences by the Commission is discussed in the original Steele brief. See Brief, at 12, Steele v. FCC, 770 F.2d 1192 (D.C. Cir. 1985) (No.84-1176) ("women have not been excluded from 'the mainstream of society' to the same extent as racial and ethnic minorities and therefore are entitled to less significant comparative merit under integration.")

220. National Telecommunications \& Info. Admin., 69 F.C.C.2d 1592, 1593 n.8 (1978). The Carter White House likewise only endorsed race preferences. See sources supra note 149.

221. 88 F.C.C.2d at 491. 
statute, the Commission concluded that women did not meet alternative eligibility requirements without the benefit of a factfinding proceeding. ${ }^{222}$ The FCC never launched such a factfinding effort. The story of FCC rulemaking in this area is one of indifference. Most Commission efforts were directed at limiting the reach of gender preferences, suggesting, as former Commissioner Glen Robinson put it, that the Commission considers these preferences a "nuisance." 223

Congress also seemed ambivalent about gender preferences. While including gender in the first lottery statute, Congress did not blink at dropping the gender specification in the second lottery statute in order to preserve race preferences. ${ }^{224}$ Congress's outrage at the FCC's reexamination of its diversity preferences likewise focused on the preservation of race preferences. In both instances, Congress appeared somewhat sympathetic to gender preferences, but far more interested in race preferences. Interest group politics played a large role in explaining this differential treatment. Minority broadcasters are a well organized, powerful lobby which is on record opposing preference points for "white women applicants."225 Women broadcasters are disorganized with relatively little political influence. ${ }^{226}$

Congress's and the FCC's passivity in the face of Lamprecht is readily understandable in the context of past legislative and administrative action. By not seeking en banc review of Lamprecht, the Commission appeared comfortable with the defeat of gender preferences. The FCC, therefore, had nothing to gain by launching a factfinding effort or requesting Supreme Court review of Lamprecht. Moreover, Congress had little incentive to pressure the FCC to seek Court review or undertake a factfinding hearing. An FCC unsympathetic to gender preferences was unlikely to substantiate the ownership-diversity nexus. ${ }^{227}$ Supreme Court review, furthermore, risked the overturning of Metro Broadcasting and, with it, race preferences. Aside from these disincentives, the FCC's oversight committees also had an agenda, too crowded to deal with the peripheral concern of gender preferences. ${ }^{228}$

Gender preferences died a sudden, unexpected, and quiet death at the hands of the D.C. Circuit. Aside from Clarence Thomas's participation in the case, Lamprecht may have gone by unnoticed, despite the fact that Lamprecht undermines a landmark Supreme Court ruling, and declares unconstitutional a congressionally mandated and FCC-approved preference scheme. Without strong

222. See Third Notice of Proposed Rulemaking, 95 F.C.C.2d 432 (1983).

223. Robinson interview, supra note 165. Accord Carvin interview, supra note 123.

224. See supra notes $158-60$ and accompanying text.

225. See Rivera Makes Commitment to NMBC, COMM. DAILY, Mar. 23, 1984, at 1; TRAC Alleges Fowles Has Shown "Clear and Unalterable Bias," COMM. DAILY, Mar. 23, 1984, at 1. Hill staffers and Commission officials both consider minority broadcasters a powerful interest and women broadcasters a comparatively unimportant interest. Crowell interview, supra note 3; Pitch interview, supra note 15.

226. See supra note 225.

227. Crowell interview, supra note 3 .

228. Id. Congress's principal concern during the spring and summer of 1992 was a massive cable television bill. 
FCC, congressional, or interest group support, the gender preference issue was politically unimportant. The questionable intrusion of a federal court into legislative and administrative affairs did not raise the stakes. The bottom line was not constitutional prerogatives, but specific policy outcomes.

\section{VII}

\section{SYNTHESIS AND CONCLUSION}

Fairness, cross-ownership, and diversity preferences are stories of power. Each of these battles reflected two fundamental challenges launched by the Fowler and Patrick Commissions to Congress's authority over broadcasting. First, the FCC raised doubts about public trustee regulations rooted in spectrum scarcity. Pointing both to technological advances and the longstanding economic argument that the "price mechanism . . . allocates resources to users without the need for government regulation," 229 the Commission advocated the substitution of marketplace solutions for existing regulations. Second, in challenging the legislatively favored regulatory regime, the Commission questioned Congress's power both to regulate broadcasting and to govern the Commission. Congress neither appreciated nor tolerated these broadsides. Rather, it badgered the Commission with angry letters and oversight hearings, and sought to stymie Commission initiatives through appropriations riders and, where necessary, freestanding legislation.

The political battles between the FCC and the Congress were unusually fierce but, in the context of the Reagan Administration's broader attack on the administrative state, not unusual. What sets these battles apart is the paramount role played by constitutional interpretation in their resolution. The FCC's free market challenge to public trustee regulation rejected the scarcity based distinction between the broadcast and print press and, with it, the presumption that government regulation yields greater broadcast diversity than do market forces. With that said, the Constitution did not figure prominently in either the FCC's regulatory challenge or Congress's counterattack. Constitutionalism was of only incidental importance to the Congress and the Commission, as baggage which necessarily accompanied free market attacks on, and public trustee justifications of, broadcast regulation.

The forms that constitutional arguments took bespeaks their secondary status. The FCC did not think constitutional arguments were sufficiently different from "public interest" claims to risk the wrath of Congress by repealing disfavored regulations as constitutionally infirm. Initial constitutional doubts about the fairness doctrine and cross-ownership lay on the periphery while the FCC questioned whether these regulations served the "public interest." ${ }^{230}$ Diversity

229. R.H. Coase, The Federal Communications Commission, 2 J. LAw \& ECON. 1, 14 (1959).

230. In News America, the FCC - -smarting from its fight with Congress over fairness-went so far as to say that only reexamination of cross-ownership would be limited to the "public interest" issue and not correlative constitutional concerns. See Corrected Brief for the FCC, supra note 135, at 21 n.6. 
preferences were never depicted as constitutionally suspect until gender preferences were struck down by the Steele panel decision. The FCC, put simply, did not see its oath to defend the Constitution adequate to the task of justifying its repeal of troublesome regulations.

The Commission's lack of constitutional fortitude is readily understandable. It was considered politically impossible to fight Congress on every matter with which the Commission preferred deregulation to regulation. The risk of political fallout was just too great. These risks were heightened by the FCC's independent agency status. Lacking the authority or prestige of a co-equal branch, the Commission felt constrained to challenge the constitutionality of programs that were congressionally approved but not statutorily mandated. Congress, moreover, placed greater demands on the Commission to follow its lead, precisely because the Commission was deemed an "arm of Congress," not part of the executive.

The Commission, in certain respects, operated within these constraints. It never sought to constitutionally repeal congressionally favored programs without some signal from the courts. In other words, rather than take the political heat for Commission-initiated constitutional repeals, the FCC sought political shelter in court edicts. The Commission's challenge then was to create the circumstances in which the courts would raise doubts about the constitutionality of disfavored programs. On fairness, the Commission called the doctrine into question with its 1985 Report and invited the courts to come in for the kill with its arguments in Meredith and R-TNDA. On cross-ownership and diversity preferences, the Commission appeared to have set the stage for judicial invalidation through its questionable advocacy in News America and Steele.

The D.C. Circuit-albeit with several caveats-assisted the Commission in its efforts. Meredith set in motion the fairness repeal; Steele prompted the reexamination of race and gender preferences. There is no doubt that the Commission sought to capitalize on these technically adverse rulings. Remand proceedings were launched in Meredith before the intervenor's request for en banc review was denied. More significantly, the en banc vacating of Steele did not prompt the Commission to defend gender preferences; instead, the FCC argued the necessity of its reexamination of all diversity preferences. This Steele inspired reexamination is all the more striking, since the Steele panel found the "Commission's authority to adopt minority preferences . . . clear.",

Commission efforts to cloak their deregulatory initiatives in the garb of court mandated constitutional analysis were rejected out of hand by the Commission's oversight committees in Congress. The House Energy and Commerce Committee, as one staffer observed, "doesn't listen to legal arguments, just ideology."232 "Power, not legal training [or a good legal argument], is the most

231. Steele v. FCC, 770 F.2d 1192, 1196 (D.C. Cir. 1985).

232. Quoted in Miller, supra note 2, at 22. 
important thing on Commerce."233 For these members of Congress, Commission retorts to the Constitution were deemed "legalistic gobbledy gook."234 Indeed, the Commission was accused of cowardice for "tak[ing] dives" in court so that it could bootstrap its deregulatory agenda to court decisions. Congress's intolerance for the niceties of constitutional analysis is also reflected in the enactment of limitation riders preventing the FCC from assessing the constitutional wisdom of cross-ownership and diversity preferences through factfinding.

This discounting of constitutional analysis reveals the obvious: The principal concerns of the FCC's overseers was the preservation of their favored policies and their authority. By the same token, when its institutional priorities or prestige was not on the table, Congress did not rise in arms to oppose constitutional interpretations with which it disagreed. For example, since the FCC supported its objectives, Congress readily responded to constitutional objections raised by the FCC to the first lottery statute. Congress's failure to respond to Lamprecht is another example. It did not matter that Lamprecht struck down legislatively mandated gender preferences, since Congress was not threatened by the decision. Gender preferences were conscientiously defended by the FCC and were without a strong advocate in Energy and Commerce. In sharp contrast, Congress's power over the FCC was challenged by the repeal of fairness, the granting of a temporary waiver to Murdoch, and the Steele reexamination. Congress, unable to strongarm the FCC through hearings, letters, and other oversight techniques, was forced to respond to these perceived power grabs through legislation codifying fairness and constraining FCC efforts to repeal diversity preferences and cross-ownership.

Congress's reliance on legislation to check the FCC thrust the White House into this conflict. On fairness, President Reagan sided with his Justice Department and Commission appointees, successfully fighting off codification on First Amendment grounds. On diversity preferences, however, Reagan parted company from Justice Department court arguments and signed appropriations measures restricting FCC reexamination. This selective attentiveness to constitutional concerns is readily understandable in personal and political terms. Reagan, a former broadcaster, cared much more about content-based fairness restrictions than some idealized color-blind constitution. The political costs of upsetting civil rights interests when a pending court decision might well strike down diversity preferences, moreover, did not warrant a veto of the reexamination funding ban.

The president, of course, plays a much larger role in defining the contours of the "constitutional dialogues" between Congress and the Commission than by simply signing or vetoing legislation. The president appoints the FCC's

233. Id.

234. See Steele Hearings, supra note 175, at 55. As one Energy and Commerce staffer explained, "[rather than] getting bogged down in fruitless debate over the possible constitutionality of the bills before them[,] [t]he Energy and Commerce Committee is quite willing to take chances on passing possibly unconstitutional legislation." Quoted in Miller, supra note 2, at 24. 
commissioners. Reagan's impact is best revealed in a letter signed by former commissioners attacking his appointees' repeal of fairness. Bush's impact, in contrast, is evidenced by his appointment of Commissioners who disavowed their predecessors' constitutional attacks on race and gender preferences in order to curry favor with their Congressional overseers. Ironically, Bush's Solicitor General (and former D.C. Circuit judge) Kenneth Starr kept faith with political conservatives and battled the Bush Commission before the Supreme Court. That Bush appointees-representing different constituencies-opposed each other in Metro Broadcasting, once again, reveals the primacy of politics over constitutional interpretation.

Metro Broadcasting also reveals that the kingpin in the struggle between free market deregulation and public trustee regulation is neither the FCC, the Congress, nor the executive. It is the judiciary. Rather than the Supreme Court, however, the pivotal judicial player is the D.C. Circuit. All FCC rulemaking and licensing decisions are subject to D.C. Circuit review. Consequently, the D.C. Circuit has evolved into a judicial overseer of the FCC. The persistence of D.C. Circuit intervention is revealed in the frequency with which that court reverses or remands FCC action. According to a 1988 Congressional Research Service memorandum, the D.C. Circuit, from January 1986 to January 1988, rejected Commission arguments in 22 of 88 cases. $^{235}$

The D.C. Circuit's activism and political awareness is a constant theme of the battles over fairness, cross-ownership, and diversity preferences. On fairness, the Commission was explicitly accused of playing judicial politics in both TRAC and Meredith. ${ }^{236} T R A C$, moreover, eschewed FCC arguments that fairness was inapplicable to teletext in order to find that fairness was not statutorily mandated. Meredith likewise encouraged the Commission to assess the constitutional wisdom of fairness, despite the fact that the remand could have been framed on narrow public interest grounds. Syracuse Peace Council offered a different type of activism. Rather than decide the constitutional question that Meredith invited, the court rewrote the FCC repeal in order to duck the constitutional question.

The resolution of cross-ownership and diversity preferences was also framed by D.C. Circuit activism. On cross-ownership, News America, reflecting panel members doubts about the constitutionality of cross-ownership, struck down the temporary waiver restriction when it could have easily viewed Murdoch as a legitimate class of one. On race preferences, $T V-9$ paid short shrift to constitutional concerns in establishing comparative hearing preferences. On gender preferences, Lamprecht severely undermined the Supreme Court's Metro Broadcasting decision in order to invalidate congressionally mandated and FCCapproved preferences.

235. See Memorandum from Janice E. Rubin to the Subcommittee on Telecommunications and Finance (on file with author).

236. Meredith Co. v. FCC, 809 F.2d 863, 874 (D.C. Cir. 1987); TRAC v. FCC, 801 F.2d 501, 509 n.5 (D.C. Cir. 1986). 
The political and ideological calculations of the FCC, the Congress, the White House, and the courts defined the battles over fairness, cross-ownership, and diversity preferences. Constitutional argumentation played a critical but secondary role in these battles. Ironically, with court decisions and FCC rulings speaking to the constitutionality of diversity preferences and fairness, the constitutional appropriateness of diversity, cross-ownership, and fairness remains up for grabs. Metro Broadcasting and Lamprecht rest their competing holdings on the presence or absence of proof that diversity in ownership spawns diversity in programming. FCC and/or congressional factfinding can strengthen or undermine the ownership-programming nexus and, with it, the continued correctness of these decisions. The fairness repeal (as well as its probable reinstatement by Congress) also lies on hotly disputed findings about the costs of fairness to program diversity. Finally, the cross-ownership policy relies on the unproven assumption that diversity of ownership yields diversity of programming. This factual predicate is also subject to challenge.

There is a certain appropriateness to this constitutional uncertainty. Battles over fairness, cross-ownership, and diversity preferences were not searches for constitutional truth. These were battles over competing policy visions and the division of power between Congress and the Commission. That these political battles should continue on into the future seems only fitting. 